\title{
WOULD BANNING FIREARMS REDUCE MURDER AND SUICIDE? A REVIEW OF INTERNATIONAL EVIDENCE
}

By Don B. Kates* and Gary Mauser**

- Don B. Kates (Ll.B., Yale, 1966) is an American criminologist and constitutional lawyer associated with the Pacific Research Institute, San Francisco. He may be contacted at dbkates@aol.com; 360-666-2688; 22608 N.E. 269th Ave., Battle Ground WS 98604

** Gary Mauser (Ph.D., U. California, Irvine, 1970) is a Canadian criminologist and university professor at Simon Fraser University, Burnaby, BC Canada. He may be contacted at www.garymauser.net, mauser@sfu.ca, and 604-291-3652. 
We gratefully acknowledge the generous contributions of: Professor Thomas B. Cole (University of North Carolina at Chapel Hill, Social Medicine and Epidemiology); Chief Superintendent Colin Greenwood (West Yorkshire Constabulary, ret.); C.B. Kates; Abigail Kohn (University of Sydney, Law); David B. Kopel (Independence Institute); Prof. Timothy D. Lytton (Albany Law School): Prof. William Alex Pridemore (University of Oklahoma, Sociology); Prof. Randolph Roth (Ohio State University, History), Prof. Thomas Velk (McGill University, Economics and Chairman of the North American Studies Program); Robert Weisberg (Edwin E. Huddleson, Jr. Professor of Law - Stanford University), and John Whitley (University of Adelaide, Economics). Any merits this paper has reflect their advice and contributions, but for errors the responsibility are ours alone. 


\section{TABLE OF CONTENTS}

\section{INTRODUCTION}

VIOLENCE: THE DECISIVENESS OF SOCIAL FACTORS

ASKING THE WRONG QUESTION

MORE GUNS, LESS CRIME?

DO ORDINARY PEOPLE MURDER?

GEOGRAPHIC, HISTORICAL AND DEMOGRAPHIC PATTERNS

1. Demographic Patterns

2. Macro-Historical Evidence: From Medieval Times to the $20^{\text {th }}$ Century

3. Summary of Macro-Historical Evidence from the Dark Ages to the $20^{\text {th }}$ Century

4. Late and More Specific Macro-Historical Evidence

5. Geographic Patterns within Nations

6. Geographic Comparisons, European Gun Ownership and Homicide Rate Comparisons

7. Geographic Comparisons, European Gun Ownership and Suicide Rates

\section{RECENT EXPERIENCE IN BRITISH COMMONWEALTH NATIONS}

1. Quasi-experiments: Do Restrictive Gun Laws Reduce Violent Crime?

2. Econometric Analyses of Canadian Gun Laws

\section{CONCLUSION}

Table 1: Europe \& Scandinavia - Gun Ownership \& Murder Rates

Table 2: Murder Rates of European Nations Which Ban Handguns As Compared to Their 
Neighbors Which Allow Handguns.

Table 3: Eastern Europe - Gun Ownership \& Murder Rates

Table 4: Intentional Deaths: U.S. v. Continental Europe Rates

Table 5: European Gun/Handgun Violent Deaths

Table 6: European Firearms - Violent Deaths 
It was not the presence of the rifle that provoked the homicide: Murderous technology is available everywhere, in every kitchen and every garage; an axe or a knife, a bottle or a car would have accomplished the same end. It is the will to use that technology that is culturally coded... this is what shapes the number of homicidal assaults in a nation." ${ }^{1}$

\section{INTRODUCTION}

The world abounds in instruments with which people can kill each other. Is the widespread availability of one of these instruments, firearms, a crucial determinant of the incidence of murder? Or do patterns of murder and/or violent crime reflect basic socie economic and/or cultural factors to which the mere availability of one particular form of weaponry is irrelevant?

International evidence and comparisons have long been offered as proof of the mantra more guns $=$ more death/fewer guns $=$ less death.$^{2}$ Unfortunately such discussions have all too

\footnotetext{
${ }^{1}$ C. Gabrielle Salfati \& Evangelos Haratsis, "Greek Homicide: A Behavioral Examination" quoting Canadian anthropologist Elliott Leyton. 5 HOMICIDE STUDIES 335, 337 (2001).

${ }^{2}$ John Godwin, MURDER USA: THE WAYS WE KILL EACH OTHER 281 (1979) (“Areas with the highest proportion of gun owner also boast the highest homicide ratios; those with the fewest gun owners have the lowest."), Nelson "Pete" Shields, GUNS DON'T DIE, PEOPLE DO 64 (N.Y.: Arbor House, 1981) (quoting and endorsing an English academic's remark "We can't help but believe that America ought to share the basic premise of our gun legislation - that the availability of firearms breeds violence."). To the same effect see e.g. Janice Somerville, "Gun Control as Immunization," AMERICAN MEDICAL NEWS January 3, 1994, p. 9 (quoting public health activist Katherine Christoffel, M.D: "Guns are a virus that must be eradicated.... Get rid of the guns, get rid of the bullets, and you get rid of the deaths."); Deane Calhoun, "From Controversy to Prevention: Building Effective Firearm Policies", INJURY PREVENTION NETWORK NEWSLETTER, Winter, 1989-90, at p. 17 ("guns are not just an inanimate object, but in fact are a social ill."); see also Paul Cotton, "Gun-Associated Violence Increasingly Viewed as Public Health Challenge," 267 JAMA (Journal of the American Medical Association) 1171-1174 (1992) at 171; Susan Baker, "Without Guns Do People Kill People?" 75 AM. J. PUB. HEALTH 587 (1985); Diane Schetky, "Children and Handguns: A Public Health Concern", 139 AM. J. DIS. OF CHILD. 229, 230;Lois A. FINGERHUT and Joel C. KLEINMAN "International and Interstate Comparisons of Homicides Among Young Males." 263 JAMA 3292, 3295 (1990), Wendy Cukier and Victor W. Sidel, THE GLOBAL GUN EPIDEMIC, FROM SATURDAY NIGHT SPECIALS TO AK-47S. Praeger Security International, Westport Conn., 2006.
} 
often been afflicted by misconceptions, factual error and focus on comparisons that are unrepresentative. It may be useful to begin with a few examples. One is the compound assertion that: (a) guns are uniquely available in the U.S. compared to other modern developed nations, which is why (b) the U.S. has by far the highest murder rate.

Though this has been endlessly repeated, in fact, b) is false and a) substantially so. The false assertion that the U.S. has the industrialized world's highest murder rate is an artifact of politically motivated Soviet minimization of true Russian homicide rates since at least 1965. As of many years before that date Russia had extremely stringent gun controls ${ }^{3}$ which were effectuated by a police state apparatus providing for extremely stringent enforcement. ${ }^{4}$ So successful was that regime that few Russian civilians have firearms and very few murders involve them. ${ }^{5}$

Yet manifest success in keeping its people disarmed has not prevented Russia from having far and away the highest murder rate in the developed world. ${ }^{6}$ In the 1960s and early '70s, gunless Russia's murder rates paralleled (generally exceeded) those of gun-ridden America. As American rates first stabilized and then steeply declined, Russian murder increased so drastically

\footnotetext{
${ }^{3}$ George Newton \& Franklin Zimring, FIREARMS AND VIOLENCE IN AMERICAN LIFE at p. 119ff., especially note 3 (Washington, D.C., Gov't Print. Off.: 1970).

${ }^{4}$ Russian law did and does flatly prohibit civilian possession of handguns and limits long guns to licensed hunters. Id. As to stringency of enforcement see Raymond Kessler, "Gun Control and Political Power", 5 LAW \& SOCIAL PROBLEMS 381 (1983) and Randy E. Barnett \& Don B. Kates, "Under Fire: The New Consensus on the Second Amendment," 45 EMORY L. J. 1139 (1996) at 1239 (Noting, among others, an unusual further element of Russian gun policy in that the Soviet Army adopted unique firearm calibers so that, even if its soldiers could not be prevented from returning with foreign gun souvenirs from foreign wars, ammunition for them would be unavailable in Russia).

5 Pridemore, William A. 2001. "Using Newly Available Homicide Data to Debunk Two Myths About Violence in an International Context: A Research Note." HOMICIDE STUDIES v. 5, pp. 267-275 (2001).

${ }^{6}$ Russian homicide data given in this article were kindly supplied us by Prof. Pridemore from his research in
} 
that by the early 1990s the Russian rate was three times higher than the U.S. As of 1998-2004 (the latest figure available for Russia) Russian murder rates were nearly four times higher than American. Much higher murder rates than the U.S. ever had also characterize the Ukraine, Estonia, Latvia, Lithuania, and various other now-independent European parts of the former U.S.S.R. ${ }^{7}$ Thus in the U.S., the former Soviet Union, and current-day Russia, "homicide results suggest that where guns are scarce other weapons are substituted in killings. ${ }^{8,}$

While American gun ownership is quite high, Table 1 infra shows many other developed nations (e.g., Norway, Finland, Germany, France, Switzerland, Greece, Denmark) with high gun availability yet murder rates as low as, and often much lower than, developed nations where guns are far fewer. For example, Luxembourg, where handguns are totally banned and ownership of any kind of gun is minimal, has a murder rate 10 times higher than gun-dense Norway and Germany where handguns are legal and gun ownership in general is very high. ${ }^{9}$

\footnotetext{
Russian ministry sources.

${ }^{7}$ The highest the U.S. homicide rate ever reported was 10.5 per 100,000 population (1980). As of 2001 the rate was below 6 . The latest rates we have for Ukraine, Belarus, and other former Soviet nations in Europe come from the mid-1990s when all were well above 10 and most were 50\% to $150 \%$ higher. See rates given in Jeffrey A. Miron, "Violence, Guns, and Drugs: A Cross-Country Analysis," 44 J. LAW \& ECON, pp. 615, 625ff. (2001).
}

Note: the U.S. rates given above are FBI reported rates. There are two different sources of U.S. murder rates. The FBI has murder data based on reports it obtains from police agencies throughout the nation. These data are slightly less complete than the alternative (used in this article unless otherwise expressly stated) rates of the U.S. Public Health Service deriving from data collected from medical examiners' offices nationwide. Though the latter data are more comprehensive, and the Public Health Service murder rate is slightly higher, they have the disadvantage of being slower to appear than the FBI homicide data.

${ }^{8}$ Gary Kleck, TARGETING GUNS: FIREARMS AND THEIR CONTROL (NY, Aldine: 1997) p. 20 (discussing patterns revealed by studies in the U.S.).

${ }^{9}$ Luxembourg's murder rate is one third higher than the U.S. rate for 1999-2003 of approximately 6.1 murders per 100,000 population.

Our assertions as to legality of handguns are based on United Nations Economic and Social Council, Commission on Crime Prevention and Criminal Justice, [Draft] UNITED NATIONS INTERNATIONAL STUDY 


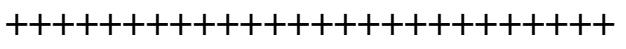

Table 1 about here

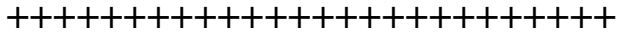

The same pattern appears when comparisons of violence to gun ownership are made within nations. Indeed, "data on firearms ownership by constabulary area in England" show "a negative correlation," ${ }^{10}$ i.e. "where firearms are most dense, violent crime rates are lowest, and where guns are least dense violent crime rates are highest" (quoting a description of what American data have also consistently shown). ${ }^{11}$ Many different data sets from various kinds of sources are summarized as follows by the leading text:

... there is no consistent significant positive association between gun ownership levels and violence rates: across (1) time within the United States; (2) U.S. cities; (3) counties within Illinois; (4) country-sized areas like England; (U.S. states; (5)

ON FIREARMS REGULATION prepared as of 1997 at p.26, table 2.1.

10 Joyce Lee Malcolm, GUNS AND VIOLENCE: THE ENGLISH EXPERIENCE (Harvard, 2002), p. 204.

${ }^{11}$ Hans Toch \& Alan Lizotte, "Research and Policy: The Case of Gun Control", in PSYCHOLOGY AND SOCIAL POLICY, edited by Peter Sutfeld and Philip Tetlock (NY Hemisphere, 1992) at 232. See also p. 234 asserting "Furthermore, the fact that national patterns show little violent crime where guns are most dense implies that guns do not elicit aggression in any meaningful way. Quite the contrary, these findings suggest that high saturations of guns in places, or something correlated with that condition, inhibit illegal aggression."

Approaching the matter from a different direction, from the earliest data (19th Century on) the American jurisdictions with the most stringent gun controls are in general precisely the ones with the highest murder rates. Conversely, American states with homicide rates as low as Western Europe's have high gun ownership, and no controls designed to deny guns to law abiding, responsible adults. Many possible reasons may be offered for these two facts. But however they are to be explained, they do not suggest that gun control reduces murder.

For examination of a wide variety of studies concluding that none support the violence reductive efficacy of gun controls see James B. Jacobs, CAN GUN CONTROL WORK ch. 7 (Oxford, Oxford U. Press, 2002), John R. Lott, MORE GUNS, LESS CRIME: UNDERSTANDING CRIME AND GUN CONTROL LAW (Chicago, U. Chi. Press, 1998), Gary Kleck, TARGETING GUNS: FIREARMS AND THEIR CONTROL ch. 11 (1997), Matthew DeZee, "Gun Control Legislation: Impact and Ideology", 5 LAW \& POLICY Q. 367 (1983); James D. Wright, Peter Rossi, Kathleen Daly, UNDER THE GUN: WEAPONS, CRIME AND VIOLENCE IN THE UNITED STATES, ch. 13 
regions of the United States; (6) nations; or (7) population subgroups .... ${ }^{12}$

A second misconception about the relationship between firearms and violence attributes Europe's generally low homicide rates to stringent gun control. That attribution cannot be accurate for murder in Europe was at an alt time low before the gun controls were introduced. ${ }^{13}$ For instance, the only English gun control during the $19^{\text {th }}$ and early $20^{\text {th }}$ Centuries was that police were to patrol without guns. During this period gun control prevailed far less in England or Europe than in certain American states which nevertheless had - and continue to have - murder rates that were and are very high comparatively. ${ }^{14}$

In this connection two recent studies are pertinent. In 2004 the U.S. National Academy of Sciences released its evaluation from an review of 253 journal articles, 99 books, 43 government publications and some empirical research of its own. It could not identify any gun control that had reduced violent crime, suicide or gun accidents. ${ }^{15}$ The same conclusion was reached in a 2003 study by the U.S. Centers for Disease Control's review of then-extant studies ${ }^{16}$ (The CDC is vehemently anti-gun and deemed its results to show not that the more guns $=$ more death mantra

(N.Y., Aldine: 1983).

${ }^{12}$ Gary Kleck, TARGETING GUNS: FIREARMS AND THEIR CONTROL 22-23 (1997), and see the preceding pages for detailed analyses of the various data.

${ }^{13}$ Barnett \& Kates, supra.

14 In the period 1900-35 Arkansas, Missouri, New Jersey, New York, Oregon, North and, South Carolina and Hawaii adopted laws variously requiring a license to own a handgun or to buy one, or banning handgun purchase altogether. And "Saturday Night Special"-type bans existed in Tennessee, Arkansas, Virginia and various other Southern states. "Toward a History of Handgun Prohibition in the United States" in Don B.. Kates (ed.), RESTRICTING HANDGUNS.

${ }^{15}$ Charles F. Wellford, John V. Pepper, and Carol V. Petrie (eds.), FIREARMS AND VIOLENCE: A CRITICAL REVIEW (National Academy of Sciences, 2004). It is perhaps not amiss to note that the review panel, which was set up during the Clinton Administration, was almost entirely composed of scholars who, to the extent their views were publicly known before their appointments, favored gun control.

16 "First Reports Evaluating the Effectiveness of Strategies for Preventing Violence: Firearms Laws" (CDC, 2003) <cdc.gov/mmwr/preview/mmwrhtml/rr5214a2.htm> 
is erroneous but only that the scores of studies it reviewed were inconclusively done.)

Stringent gun controls were not adopted in England and Western Europe until after WWI. Consistent with the outcomes of the American studies just mentioned, these strict controls did not stem the general trend of ever-growing violent crime throughout the post-WWII industrialized world including the U.S. and Russia. Prof. Malcolm's study of English gun law and violent crime summarizes that nation's $19^{\text {th }}$ and $20^{\text {th }}$ Century experience as follows:

The peacefulness England used to enjoy was not the result of strict gun laws. When it had no firearms restrictions $\left[19^{\text {th }}\right.$ and early $20^{\text {th }}$ Century $]$ England had little violent crime, while the present extraordinarily stringent gun controls have not stopped the increase in violence or even the increase in armed violence....

Armed crime, never a problem in England, has now become one. Handguns are banned but the kingdom has millions of illegal firearms. Criminals have no trouble finding them and exhibit a new willingness to use them. In the decade after 1957 the use of guns in serious crime increased a hundredfold. ${ }^{17}$

In the late 1990s England moved from stringent controls to a complete ban on handguns and many types of long guns. Hundreds of thousands were confiscated from owners law abiding enough to turn them in. Without suggesting this caused violence, the bans' ineffectiveness was such that by year 2000 violent crime had so increased that England had the developed world's highest violent crime rate, far surpassing even the U.S. ${ }^{18}$ Today English news media headline

\footnotetext{
17 Joyce Lee Malcolm, GUNS AND VIOLENCE: THE ENGLISH EXPERIENCE (Cambridge, Harvard, 2002) at pp. 209 and 219.

${ }^{18}$ John van Kesteren, et al., "Criminal Victimization in 17 Industrialised [sic] Countries: Key Findings from the 2000 International Crime Victimization Surveys" (Feb. 23, 2001). The surveys involved were conducted under the auspices of the governments of each nation and the general supervision of the University of Leiden and the
} 
violence in terms redolent of the doleful, melodramatic ones that for so long characterized American news reports. ${ }^{19}$

The divergence between the U.S. and the British Commonwealth became especially pronounced during the 1980s and 1990s. During these two decades, while Britain and the Commonwealth were making lawful firearm ownership increasingly difficult, more than 25 states in the United States passed laws allowing responsible citizens to carry concealed handguns. There are now 40 states, including more than $60 \%$ of the population, where qualified citizens can get such a handgun permit ${ }^{20}$. As a result, the number of Americans who are allowed to carry concealed handguns in shopping malls, on the street, and in their cars has grown to 3.5 million

Dutch Ministry of Justice.

${ }^{19}$ S e.g.: "Violent Crime is Out of Control" July 21, 2005, http://uk.news.yahoo.com/050721/140/fntfz.html; NEWS TELEGRAPH, March 13, 2005 " "We are Reeling with the Murders; We Are in a Crisis with Major Crime"” (quoting a police chief) [http://news. Telegraph.co.uk]; LONDON EVENING STANDARD, April 12, 2005 "Police fear gun crime explosion" [http://www.thisislondon.com/news/londonnews/articles/

17867375? source=Evening\%20Standard]; BBC News: May 21, 2003, "Gun Crimes Growing 'Like Cancer,"” as well as July 16, 2001 "Handgun Crime 'Up" Despite Ban;" July 12, 2002: "[PM Blair] Pledge[s] to Tackle Soaring Street Crime; Nov. 7, 2002, "Scottish Gun Crime Soaring;"; Jan. 12, 2003. See also: PUNCH, "Britain's Tough Gun Control Laws Termed Total Failure: Land of Hope and Gunrunning," May 3-16, 2000; NEW STATESMAN, "The British Become Trigger Happy, Nov. 5, 2001; and Reuters (London) Jan. 9, 2003: "Gun crime soars in Britain"”, and the following articles for the dates indicated a) from the LONDON TIMES, Jan. 16, 2000: "Killings Rise As 3 Million Illegal Guns Flood Britain."; October 13, 2002: "Murder rate soars to highest for a century"; Jan. 9, 2003: "Handgun Crime Rises by 46\% [in 2002]; b) from the INDEPENDENT NEWS: January 15, 2002 "Police Move to Tackle Huge Rise in Gun Crime; 27 December 2002 "Firearms amnesty to tackle surge in gun crime" [http://news.independent.co.uk/uk/crime/story.jsp?story=364549; c) from the LONDON TELEGRAPH: 25 August, 1999: "[Home Secretary Jack] Straw Braced for 20\% Increase in Crime Rate; 17 July 2001, "Gun crime rises despite Dunblane pistol ban"; 17 August 2001, "Gun killings double as police claim progress"; 3 January 2002, "Police fear crime explosion as school-age muggers graduate to guns"; Feb. 24, 2002, "Gun crime trebles as weapons and drugs flood British cities."

${ }^{20}$ In March 2006, Kansas and Nebraska became the $39^{\text {th }}$ and $40^{\text {th }}$ states, respectively, to pass "shall issue" concealed carry legislation. In Kansas, the state legislature voted to overturn the Governor's veto of the bipartisan legislation. Carl Manning, "Update 2: Kansas House Overrides Veto of Gun Bill." THE ASSOCIATED PRESS. http://www.forbes.com/technology/feeds/ap/2006/03/23/ap2618492.html. In Nebraska, the governor signed the bill as passed by the state legislature. O'Hanlon, Kevin, "Concealed-weapons bill adopted," THE ASSOCIATED PRESS, JOURNAL STAR, Lincoln, Nebraska. Friday, March 31, 2006, http://www.journalstar.com/articles/2006/03/31/legislature/doc442c57ae8eb55289989057.txt 
men and women ${ }^{21}$. Arguably, these new laws have contributed to the drop in homicide and violent crime rates. Based on 25 years of correlated statistics from all of the more than 3,000 American counties John Lott and David Mustard conclude that adoption of these statutes has so deterred criminals from confrontation crime as to cause murder and violent crime to fall faster in states that adopted this policy than in the states that did not. ${ }^{22}$

As indicated in the preceding footnote, the notion that more guns reduce crime is highly controversial. What the controversy has obscured from view is the corrosive effect of the Lott and Mustard work on the faith that more guns = more murder. As of 2006, 40 states have adopted laws under which guns became vastly more available to law abiding, responsible adults, i.e., 3.5 million Americans are legally entitled not just to keep guns in their homes but to carry concealed handguns with them wherever they go. But this has not resulted in more murder or violent crime in these states. Rather adoption of these statutes has been followed by very significant reduction in murder and violence in those states.

It must be understood that to determine whether it was this expansion of gun availability that caused reductions in violent crime requires taking account of various other factors that might also be deemed to have contributed. For instance, one of Lott's major critics attributes much of the

${ }^{21}$ See Don Kates, in Timothy Lytton, 2005, op cit, p.64.

${ }^{22}$ See John R. Lott Jr. \& David B. Mustard, Crime, Deterrence, and Right-to-Carry Concealed Handguns, 26 JOURNAL OF LEGAL STUDIES 1-68 (1997); John Lott, MORE GUNS, LESS CRIME. $2^{\text {nd }}$ Ed. Chicago: University of Chicago Press, 2000. Several critics have now replicated Lott's work using additional or different data, additional control variables, or new or different statistical techniques they deem superior to those Lott used. Interestingly, the replications all confirm Lott's general conclusions; some even find that Lott underestimated the crime-reductive effects of allowing good citizens to carry concealed guns. See the seven articles printed in the Oct. 1991 issue of THE JOURNAL OF LAW AND ECONOMICS (v. 44); also Florenz Plassman \& John Whitley, "Confirming 'More Guns, Less Crime,'" STANFORD LAW REVIEW 55 (2003) 1313. For what it's worth, Lott, in THE BIAS AGAINST GUNS. Washington, DC: Regnery, 2003, reiterates, and extends his findings, is endorsed by three Nobel laureates. 
drop in violent crime from the 1990s on to the legalization of abortion in the 1970s which he argues resulted in the non-birth of vast numbers of children who would have been disproportionately involved in violent crime had they existed in the 1990s (the Donohue-Levitt thesis $)^{23}$.

The Lott-Mustard studies apparently took no account of the Donohue-Levitt thesis. Lott and Mustard did take at least some account of two American phenomena which many people think might have been responsible for then 1990s crime reduction. The United States dramatically increased both its prison population and the number of executions. The prison population in the U.S. tripled during this time period, jumping from around 100 prisoners per 100,000 in the late 1970 s to over 300 per 100,000 people in the general population in the early $1990 \mathrm{~s}^{24}$. In addition, executions in the United States soared from about 5 per year in the early 1980s to more than 27 per year in the early $1990 \mathrm{~s}^{25}$. None of these trends are reflected in Commonwealth countries.

Whatever the reason, the upshot is that violent crime, and homicide in particular, have plummeted in the United States over the past 15 years. ${ }^{26}$ The fall in the American crime rate is even more impressive when compared with the rest of the world. In 18 of the 25 countries

\footnotetext{
${ }^{23}$ John J. Donohue III \& Steven D. Levitt, The Impact of Legalized Abortion on Crime, 116 Q. J. ECON. $379,(2001)$.

${ }^{24}$ See Allen Beck and Paige Harrison, CORRECTIONAL POPULATIONS IN THE UNITED STATES, 1997, AND PRISONERS IN 2004, Bureau of Justice Statistics, 2005, http://www.ojp.usdoj.gov/bjs/glance/tables/incrttab.htm

${ }^{25}$ See Thomas Bonczar and Tracy L. Snell, CAPITAL PUNISHMENT, 2003Bureau of Justice Statistics Bulletin, November 2004, NJC 206627.

${ }^{26}$ These trends are easily seen in the Uniform Crime Reports (UCR) data on the website of the federal Bureau of Investigation (http://www.fbi.gov/ucr/ucr.htm).
} 
surveyed by the British Home Office, violent crime increased during the $1990 \mathrm{~s}^{27}$. This contrast should provoke thinking people to wonder what happened in those nations adopting policies based on the belief that introducing more and more restrictive firearm laws would reduce criminal violence. Perhaps the United States is doing something right. Further research is required to identify more precisely which elements of their approach is the most important, or whether all three elements acting in concert with each other was necessary to reduce criminal violence.

This article will examine a broad range of international data that bear on two distinct but interrelated questions: first, whether widespread firearm access is an important contributing factor in murder and/or suicide, and second, whether the introduction of laws that restrict general access to firearms has been successful in reducing violent crime, homicide or suicide. Our conclusion from the available data is that suicide, murder and violent crime rates are determined by basic social, economic and/or cultural factors with the availability of any particular one of the world's myriad deadly instrument being irrelevant. ${ }^{28}$

${ }^{27}$ See G. Barclay, C. Tavare, and A. Siddique (2001). INTERNATIONAL COMPARISONS OF CRIMINAL JUSTICE STATISTICS, 1999. Issue 6/01 (May). Digital document available from http://www.homeoffice.gov.uk/rds/.

${ }^{28}$ See Miron, supra: "What factors do explain cross-country differences in violence? One possible answer is that culture--history, social norms, and the like--makes attitudes toward both violence and gun control substantially different across countries, simultaneously explaining both the differences in violence rates and the differences in gun control laws. Culture is likely an important determinant of cross-country differences in violence, but explanations based on culture are difficult to examine empirically. An alternative possibility is that various economic and social factors, such as demographics, ethnic diversity, education, income, inequality, deterrence, and the like, all contribute to the differences in violence across countries. There is empirical support for many of these effects, but it is not clear why such factors would explain the large differences in violence between the United States and other rich countries, nor is it clear how these factors can explain the existing patterns of gun availability, gun control, and violence." $44 \mathrm{~J}$. LAW \& ECON at 616.

Prof. Miron offers studies and evidence suggesting that violence is substantially heightened in nations which, like the U.S., seriously attempt to enforce bans on narcotics. 


\section{VIOLENCE: THE DECISIVENESS OF SOCIAL FACTORS}

One reason the extent of gun ownership in a society does not spur the murder rate is that murderers are not spread evenly throughout the population. Analysis of perpetrator studies shows that violent criminals, (and this is especially true of murderers) "almost always have a long history of involvement in criminal behavior.." ${ }^{29}$ So it would not appreciably raise violence if all law abiding, responsible people had firearms because they are not the ones who rape, rob or murder. ${ }^{30}$ By the same token violent crime would not fall if guns were totally banned to civilians. As the respective examples of Luxembourg and Russia suggest,${ }^{31}$ the kinds of people who murder will either find guns despite severe controls or will find other weapons with which to kill.

Startling as the foregoing may seem, it represents the cross-national norm, not some bizarre departure from it. If the mantra (more guns $=$ more death/fewer guns $=$ less death) were true should not broad based cross-national comparisons show that nations with higher gun ownership per capita consistently have more death? But nations with higher gun ownership rates do not have higher murder (or suicide) rates than do those with lower gun ownership. Indeed many high gun ownership nations have much lower murder rates. Consider the wide divergence in murder rates among Continental European nations with widely divergent gun ownership rates. (Actually, those nations with least gun ownership generally seem to have the highest murder rates.)

The non-correlation between gun ownership and murder is reinforced by examination of

\footnotetext{
${ }^{29}$ Delbert S. Elliott, "Life Threatening Violence is Primarily a Crime Problem: A Focus on Prevention," 69 COLO. L. REV. 1081-1098 at 1089 (1998), emphasis added.

${ }^{30}$ See discussion under "Do Ordinary People Murder" infra.

${ }^{31}$ See footnotes 3-8 and Table 1 supra.
} 
statistics from larger numbers of nations across the developed world. Comparison of "homicide and suicide mortality data for thirty-six nations (including the United States) for the period 19901995" to gun ownership levels showed "no significant (at the 5\% level) association between gun ownership and the total homicide rate. ${ }^{32}$ Consistent with this is a later European study of data from 21 nations in which "no significant correlations [of gun ownership levels] with total suicide or homicide rates were found." 33

\section{ASKING THE WRONG QUESTION}

However unintentionally, the irrelevance of focus on weaponry is highlighted by the most common theme in more guns = more death arguments. Epitomizing this theme is a World Health Organization (WHO) report solemnly asserting, "The easy availability of firearms has been associated with higher firearm mortality rates." ${ }^{34}$ The authors apparently assume that (for instance) if denied firearms potential suicides will decide to live rather than turning to knives, poisons, hanging, jumping from great heights or the numerous other available suicide

\footnotetext{
${ }^{32}$ Gary Kleck, TARGETING GUNS, supra p. 254. Though we have quoted the finding as to murder rates, the study also found no correlation to suicide rates.

${ }^{33}$ Quoted from the Abstract to Martin Killias, John van Kesteren \& Martin Rindlisbacher, 2001: "Guns, Violent Crime, and Suicide in 21 Countries, "CANADIAN J. OF CRIMINOLOGY 43:429-448 (2001) It bears emphasis that the authors - who are deeply anti-gun - emphasize the "very strong correlations between the presence of guns in the home and suicide committed with a gun." (our italics) - as if there were some import to the death being by gun rather than by hanging, poison, etc., etc. See discussion in the next section of this article.

${ }^{34}$ W.H.O., SMALL ARMS AND GLOBAL HEALTH, p. 11 (W.H.O., Geneva, 2001), emphasis added. This irrelevancy is endlessly repeated, e.g.: Wendy Cukier, "Small Arms and Light Weapons: A Public Health Approach," 9 BROWN J. WORLD AFFAIRS 261, 266, 267 (2002) ("Studies have shown that rates of small arms death are linked to small arms accessibility....In industrialized countries, studies have shown that accessibility is related to firearm death rates... Other studies have examined the rates of death from firearms across regions, cities, high income countries [etx]...." Our italics); the article "Confronting the Small Arms Pandemic" in the April 2002 BRITISH MEDICAL JOURNAL by the president of Physicians for Global Survival, Neil Arya; and .EG Krug, KE Powell and LL Dahlberg, "Firearm-Related Deaths in the United States and 35 Other High- and Upper-MiiddleIncome Countries," INTERNATIONAL JOURNAL OF EPIDEMIOLOGY 1998;27:214-221 (discussed in the text
} 
mechanisms. The evidence, however, indicates that all that is accomplished by the removal of one particular means from people who are motivated to suicide by social, economic, cultural or other circumstances is their killing themselves by some other means. ${ }^{35}$ Thus it is not just the murder rate in gun-less Russia that is four times higher than the American rate; the Russian suicide rate is also about four times higher than the American. ${ }^{36}$

There is no social benefit in decreasing the availability of guns if the result is only to increase the use of other means of suicide and murder, resulting in more or less the same amount of death. Elementary as this point is, proponents of the more guns = more death mantra seem oblivious to it. One study solemnly asserts that Americans are more likely to be shot to death than people in the world's other 35 "richest nations," ${ }^{37}$ While this is literally true, it is irrelevant except, perhaps to people who are neurotically terrified not of death per se but just by gunshot. A fact of greater concern to normal people - but which the study fails to mention -- is that per capita murder overall is only half as frequent in the U.S. as in several of those other wealthy nations where gun murder is rarer, but murder by strangling, stabbing and/or beating is much

infra).

${ }^{35}$ See Jacobs, CAN GUN CONTROL WORK supra at 120 ("if the Brady Act did have the effect of modestly reducing firearms suicides ... this effect was completely offset by an increase of the same magnitude in non-firearm suicide" resulting in the same number of deaths). To the same effect, see the studies collected and reviewed by Kleck in ch. 8 of his TARGETING GUNS: FIREARMS AND THEIR CONTROL (Aldine, 1997). Indeed - though without noting the significance -- eight pages earlier (p. 3) the WHO Report states that world-wide "firearms accounted for only one-fifth of all suicides, just ahead of poisoning... [self-] strangulation, [i.e. hanging] was the most frequently used method of suicide."

${ }^{36}$ In 1999, the latest year for which we have Russian data available, the American suicide rate was 10.7. while the Russian suicide rate was c. 41 per 100,000 people, Compare William A. Pridemore \& Andrew L. Spivak, "Patterns of Suicide in Russia," forthcoming in SUICIDE AND LIFE THREATENING BEHAVIOR (2003) to NATIONAL VITAL STATISTICS REPORTS v. 49 \# 8, "Deaths: Final Data for 1999" (issued September 25, 2001) authors: Donna L. Hoyert, Elizabeth Arias, Betty L. Smith, Sherry L. Murphy \& Kenneth D Kochanek.

${ }^{37}$ Quoting the EG Krug, KE Powell and LL Dahlberg article supra. 
more frequent. $^{38}$

Of course it may be speculated that murder rates around the world be higher if guns were more available. But there is simply no evidence to support this. Like any speculation it is not subject to conclusive disproof. But it flies in the face of the European data in Table 1 and the studies across 36 and 21 nations already discussed. These show no correlation of high gun ownership nations having more murder per capita or lower gun ownership nations having less. ${ }^{39}$ To reiterate, the determinants of murder and suicide are basic social, economic and cultural factors not the prevalence of some mere form of deadly mechanism. In this connection recall that the American jurisdictions which have the highest violent crime rates are precisely those with the most stringent gun controls. ${ }^{40}$ This correlation does not necessarily prove pro-gun advocates correct that gun controls actually encourage crime by depriving victims of the means of self-defense. The explanation of this correlation may be political rather than criminological: Jurisdictions afflicted with violent crime tend to severely restrict gun ownership. But this does not suppress the crime for banning guns can not alleviate the socio-cultural and/or economic factors

\footnotetext{
${ }^{38}$ The 36 countries which the authors chose to cover were those having highest GNP per capita income as listed in the World Bank's 1994 World Development Report. Resort to David C. Stolinsky, "America: The Most Violent Nation?," 5 MEDICAL SENTINEL 199, 200 (2000) shows three of those nations, Argentina, Brazil, and Estonia, had about $100 \%$ higher overall murder rates than the U.S. Readers may question the value of comparing the U.S. to those particular nations. So let us emphasize that it was Krug, et. al who chose to do so. All we have done is provide full murder rate information as opposed to the partial information provided by the authors.

${ }^{39}$ Kleck, TARGETING GUNS, supra p. 254; Killias, et al., CANADIAN J. OF CRIMINOLOGY supra.

${ }^{40}$ See notes, sources, and material cited at notes 111- 113 and accompanying text infra. For at least 30 years gun advocates have echoed in more or less identical terms one's observation that $20 \%$ of American homicide is concentrated in four cities having only $6 \%$ of the total population, but the nation's most restrictive gun laws. Neal Knox, Hearings on Crime before the Subcomm. on Crime of the House Comm. on the Judiciary, 94 Cong. 1st Sess., pt. 7, p. 2394. In Oct. 2000 the head of another gun group ridiculed a Handgun Control "scorecard" for its misleading attempts to inversely correlate violent crime rates to the extent of the various states' gun controls. He points out that, in fact, the states with the most restrictive gun laws consistently have the highest murder rates while those with the least controls had the lowest homicide rates. Larry Pratt, "HCI's Scorecard," Oct., 2000 at http://gunowners.org/op0042.htm.
} 
that are the real determinants of violence and crime rates. As a result areas with severe violence problems tend correlatively to have severe gun control, leading to the appearance that gun controls actually cause violence. ${ }^{41}$

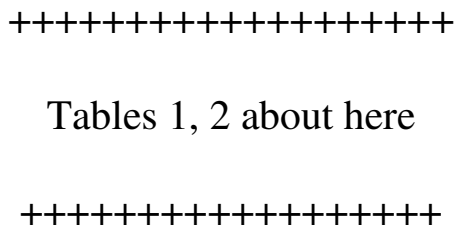

Once again, we are not arguing these Table 2 data show that gun control causes nations to have much higher murder rates than do neighboring nations that allow handguns. Rather, we are asserting a political causation for the observed correlation that nations with stringent gun controls tend to have much higher murder rates than nations that allow guns. That political causation is that nations which have violence problems tend to adopt severe gun controls but these do not reduce the violence for violence is determined by basic socio-cultural and economic factors which are not affected by simplistic focusing on the mere availability of one among numerous potential deadly weapons.

The point is exemplified by the conclusions of the premier study of English gun control. Done by a senior English police official as his thesis at the Cambridge University Institute of Criminology and later published as a book, it found (as of the early 1970s):

Half a century of strict controls has ended, perversely, with a far greater use of

\footnotetext{
${ }^{41}$ It is noteworthy that the correlation more gun control/more crime seems to hold true in other nations,
} 
[handguns] in crime than ever before. No matter how one approaches the figures one is forced to the rather startling conclusion that the use of firearms in crime was very much less [in England before 1920] when there were no controls of any sort and when anyone, convicted criminal or lunatic, could buy any type of firearm without restriction. $^{42}$

Of course Chief Superintendent Greenwood was not urging that the law allow lunatics and criminals to own guns. The point is that violence will be rare when the basic socio-cultural and economic determinants so dictate; and conversely, crime will rise in response to changes in those determinants -- without much regard to the mere availability of some particular weaponry or the severity of laws against it.

\section{DO ORDINARY PEOPLE MURDER?}

The more guns $=$ more death mantra seems plausible to the many people who think of murders as mostly involving ordinary people who kill because they have access to a firearm when they get angry. If that were true, murder might well increase where people have ready access to firearms. But we have already seen there is no such correlation. Nations and areas with more guns per capita do not have higher murder rates than those with less. ${ }^{43}$

Nevertheless an oft-repeated litany holds: that a "gun in the closet to protect against burglars will most likely be used to shoot a spouse in a moment of rage....The problem is you and

\footnotetext{
though much less strikingly than in the U.S.. Miron, 44 J. LAW \& ECON at 628 supra.

${ }^{42}$ Colin Greenwood, FIREARMS CONTROL: ARMED CRIME AND FIREARMS CONTROL IN ENGLAND AND WALES 243 (London: Routledge, Kegan, Paul, 1972).

${ }^{43}$ See Tables 1-3 and notes 1-5 supra and 95-97 infra.
} 
me -- law-abiding folks"; that banning handguns will "protect us against the most likely source of handgun murder: ordinary citizens. ${ }^{44}$; that "most gun-related homicides ... are the result of impulsive actions taken by individuals who have little or no criminal background and who are known to the victims"; ${ }^{45}$ that "the majority of homicide[s occur] ... not as a result of criminal activity, but because of arguments between people who know each other;" that each year there are thousands of gun murders "by law-abiding citizens who might have stayed law-abiding if they had not possessed firearms.",46

These comments are truly remarkable in that they not only rest on no evidence whatever but fly in the face of facts that have so uniformly been established by homicide studies dating back to at least the 1890 s as to have become "criminological axioms." ${ }^{47}$ Insofar as studies (of which those detailed below are but a representative sample) focus on perpetrators they show that neither a majority, nor many, nor virtually any murderers are ordinary "law abiding folks", "law abiding citizens." Rather, almost all murderers are extreme aberrants with life histories of violence, psychopathology, substance abuse and other dangerous behaviors. "The vast majority of persons involved in life-threatening violence have a long criminal record with many prior contacts

\footnotetext{
44 The last two quotes come from, respectively David Kairys "A Carnage in the Name of Freedom", PHILADELPHIA INQUIRER, September 12, 1988, and Nicholas Dixon, Why We Should Ban Handguns in the United States, 12 ST. LOUIS U. PUB. L. REV. 243, 265-66 (1993) and are recycled in Frank J. Vandall “A Preliminary Consideration of Issues Raised in the Firearms Sellers Immunity Bill," A PRELIMINARY CONSIDERATION OF ISSUES RAISED IN THE FIREARMS SELLERS IMMUNITY BILL 38 AKRON L. RE.V1 13, 118 -19 (2005) at footnotes 28 and 32.

${ }^{45}$ Robert Spitzer, THE POLITICS OF GUN CONTROL (Chatham, N.J., Chatham House 1995) 186, emphasis added.

46 The last two quotes given are from, respectively: the Violence Policy Center's blurb describing itself, "About the Violence Policy Center" and the National Coalition to Ban Handguns' undated, unpaginated pamphlet entitled "A Shooting Gallery Called America" (emphasis in original).

${ }^{47}$ David Kennedy \& Anthony Braga, "Homicide in Minneapolis: Research for Problem Solving," 2 HOMICIDE STUDIES 263-290 (1998).
} 
with the justice system." ${ }^{48}$ "Thus homicide - [whether] of a stranger or [of] someone known to the offender -- 'is usually part of a pattern of violence, engaged in by people who are known ... as violence prone.",49 Though only $15 \%$ of Americans have criminal records ${ }^{50}$ roughly 90 percent of adult murderers have adult records, with an average adult career of six or more years, including four major felonies. ${ }^{51}$ These national data dovetail with data from local 19th and 20th Century studies. For example: "Victims as well as offenders [in 1950s and 1960s Philadelphia murders] finally, tended to be people with prior police records, usually for violent crimes such as assault, and both had typically been drinking at the time of the fatal encounter." ${ }^{2}$ "The great majority of both perpetrators and victims of [1970s Harlem] assaults and murders had previous [adult] arrests, probably over $80 \%$ or more;" 53 1990s Boston police and probation officers agreed that virtually all juveniles who murder are gang members, though the killing is not necessarily gang-directed, e.g. a gang member who stabs his girlfriend to death in a fit or anger; ${ }^{54}$ Regardless of their arrests for other crimes, $80 \%$ of 1997 Atlanta murder arrestees had at least one prior drug offense with $70 \%$ having 3 or more prior drug offenses. ${ }^{55}$

\footnotetext{
${ }^{48}$ Delbert S. Elliott, "Life Threatening Violence is Primarily a Crime Problem: A Focus on Prevention," 69 COLO. L. REV. 1081-1098 at 1093 (1998), collecting studies.

${ }^{49}$ Gerald D. Robin, VIOLENT CRIME AND GUN CONTROL (Cincinnati, Academy of Criminal Justice Sciences: 1991) at p. 47.

${ }^{50}$ Mark Cooney, "The Decline of Elite Homicide," 35 CRIMINOLOGY 381, 386 (1997).

${ }^{51}$ Gary Kleck \& Don B. Kates, ARMED: NEW PERSPECTIVES ON GUN CONTROL 20-21 (Prometheus 2001).

${ }^{52}$ Roger Lane, MURDER IN AMERICA: A HISTORY (Ohio U. Press, 1997) p. 259

${ }^{53}$ A. Swersey and E. Enloe, HOMICIDE IN HARLEM (N.Y., Rand, 1975) 17.

${ }^{54}$ Anthony Braga, Anne M. Piehl \& David M. Kennedy, "Youth Homicide in Boston: An Assessment of the Supplementary Homicide Report Data," 3 HOMICIDE STUDIES 277, 283-84 (1999)

55 Dean G. Rojek, "The Homicide and Drug Connection", p. 135 in Paul H. Blackman, et al, THE VARIETIES OF HOMICIDE AND ITS RESEARCH (Quantico, VA, F.B.I. Academy, 2000).
} 
Several of the more recent homicide studies just reviewed were done by the Kennedy School at Harvard whose latest study found almost all arrested murderers to have prior arrests with many being known to police as gang members. ${ }^{56}$

That murderers are not ordinary, law abiding responsible adults is further documented in other sources. Psychological studies of juvenile murderers variously find $80-100 \%$ to be psychotic or have psychotic symptoms. ${ }^{57}$ Only $75 \%$ of Massachusetts domestic murderers in the years 1991-95 "had a prior [adult] criminal history," but 23.6\% "were under an active restraining order at the time of the homicide. Forty percent of perpetrators had a history of having been under a restraining order at some time prior to the homicide, taken out by the victim or some other person." ${ }^{58}$

This last study is one of many exposing the false concept that many murders involve ordinary people killing spouses in a moment of rage. While there are many domestic homicides, such murders do not occur in ordinary families nor are the murderers ordinary, law-abiding adults. "The day-to-day reality is that most family murders are preceded by a long history of assaults" by the perpetrator (the man) upon his mate. ${ }^{59}$ One study of such murders found "A

\footnotetext{
56 "Some $95 \%$ of homicide offenders, $82 \%$ of aggravated gun assault offenders, $47 \%$ of homicide victims, and $29 \%$ of aggravated gun assault victims were arraigned at least once in Massachusetts courts before they committed their crime or were victimized. Individuals that were previously known to the criminal justice system were involved in a wide variety of offenses and, on average, committed many prior crimes... On average, aggravated gun assault offenders had been arraigned for 12 prior offenses, homicide offenders had been arraigned for 9 prior offenses...." Anthony A. Braga, Jack McDevitt, \& Glenn L. Pierce, "Understanding and Preventing Gang Violence: Problem Analysis and Response Development in Lowell, MA," [to be published in POLICE QUARTERLY (2005, Volume 8, Number 3, specific page numbers unknown)]

57 Wade C. Myers \& Kerrilyn Scott, "Psychotic and Conduct Disorder Symptoms in Juvenile Murderers," 2 HOMICIDE STUDIES 160, 161-63 (1998).

${ }^{58}$ Linda Langford, Nancy Isaac \& Sandra Adams, "Criminal and Restraining Order Histories of Intimate Partner-Related Homicide Offenders in Massachusetts, 1991-95" in Blackman, VARIEIES OF HOMICIDE, supra.

${ }^{59}$ See Murray A. Straus, "Domestic Violence and Homicide Antecedents", 62 BULLETIN OF THE N.Y.
} 
history of domestic violence was present in $95.8 \%$ " of cases. ${ }^{60}$ Quotations like the following are a routine feature of domestic homicide studies:

The overriding theme to emerge from these cases was that [domestic] partner homicide is most often the final outcome of chronic women battering. ${ }^{61}$ [Citing studies from Detroit and Kansas City,] 90\% of all the family homicides were preceded by previous disturbances at the same address, with a median of 5 calls per address. ${ }^{62}$

This study reemphasizes the central role of domestic violence as an antecedent to partner femicide. ${ }^{63}$

The only kind of evidence cited to support the mythology that most murderers are ordinary people is that many murders arise from arguments and/or occur in homes and between acquaintances. ${ }^{64}$ Those citing these bare facts as if they were relevant seem to be laboring under the unexamined assumption that criminals don't have acquaintances or homes or arguments - so if most murders involve these things, the perpetrators must be non-criminals. Of the many studies belying this, the broadest analyzed a year's national data on gun murders occurring in homes and

ACADEMY OF MEDICINE 446, 454, 457 (1986) and "Medical Care Costs of Intrafamily Assault and Homicide", 62 N.Y. ACAD. OF MED. 556, 557 fn. (1986).

${ }^{60}$ Paige Hall-Smith, Kathryn E. Moracco \& John D. Butts, "Partner Homicide in Context," 2 HOMICIDE STUDIES 400, 410 (1998). The 95.8 is the percentage of murders in the study as to which sufficient information was available on the background of the parties.

${ }^{61}$ Hall-Smith, et al., supra at 411.

${ }^{62}$ Robin, supra, at 47. 422-446.

${ }^{63}$ Kathryn E. Moracco, Carol W. Runyan, \& John D. Butts, "Femicide in North Carolina, 1991-1993," pp.

${ }^{64}$ See, e.g., Spitzer and Kairys, supra and Adler et al., Correspondence, 272 JAMA 1409 (1994), responding to criticism on this point of their article Karl P. Adler \& J.A. Barondess, et al. "Firearms Violence and Public Health: Limiting the Availability of Guns", 271 JOURNAL OF THE AMERICAN MEDICAL ASSOCIATION, 1281 (1994). 
between acquaintances. It found "the most common victim-offender relationship" was "where both parties knew one another because of prior illegal transactions." ${ }^{65}$

Thus the term "acquaintance homicide" does not refer to murders between ordinary acquaintances. Rather it refers to, for example: drug dealers being killed by competitors or customers; gang members being killed by members of the same or rival gangs; and women being killed by stalkers or abusers who have brutalized them on previous occasions. Federal and state laws already prohibit guns to most such aberrants. ${ }^{66}$

Obviously there are certain people who should not be allowed to own any instrument more deadly than a toothpick. Reasonable as such prohibitions are, it is unrealistic to think those people will comply any more readily than they do with laws against violent crime. ${ }^{67}$ In any event, there is no reason for laws against gun possession by ordinary, law abiding responsible adults since they virtually never murder. Since such adults are far more likely to be victims of violent crime than to commit it, disarming them is not just unproductive but counter-productive. ${ }^{68}$

${ }^{65}$ Gary Kleck, TARGETING GUNS: FIREARMS AND THEIR CONTROL 236 (1997) (emphasis added) analysis of U.S. Bureau of Justice Statistics data on murder defendants being prosecuted in the 33 largest U.S. urban counties.

${ }^{66}$ Current federal law prohibits gun possession by minors, persons previously convicted of domestic violence misdemeanors, or of any felony, or who have been involuntarily committed to mental institutions or by drug addicts. 18 U.S.C. sec. $921 \mathrm{ff}$; as to state gun laws see, e.g., Cal. Penal C. §§ 12021ff., 12072, 12076, 12100-1, 12551-2 and W \& I. C. $\S \S 8100-8105$. For a summary of the general patterns of federal and state guns laws see CAN GUN CONTROL WORK, supra, ch. 2.

$67 " .$. there is no good reason to suppose that people intent on arming themselves for criminal purposes would not be able to do so even if the general availability of firearms to the larger population were seriously restricted. Here it may be appropriate to recall the First Law of Economics, a law whose operation has been sharply in evidence in the case of Prohibition, marijuana and other drugs, prostitution, pornography, and a host of other banned articles and substances, namely, that demand creates its own supply. There is no evidence anywhere to show that reducing the availability of firearms in general likewise reduces their availability to persons with criminal intent or that persons with criminal intent would not be able to arm themselves under any set of general restrictions on firearms." UNDER THE GUN, supra at 137-38; italics in original.

${ }^{68}$ This article will not discuss the defensive use of firearms beyond making the following observations: While there is great controversy about that subject, it is a misleading controversy in which anti-gun advocates' deep 


\section{MORE GUNS, LESS CRIME?}

Anti-gun activists are not alone in their faith that widespread firearm ownership substantially affects violent crime rates. The same belief also characterizes many pro-gun activists. Of course their faith leads them to the opposite conclusion, i.e., that widespread firearm ownership reduces violence by deterring criminals into non-confrontation crimes such as theft from unoccupied commercial or residential premises. Superficially, the evidence for this deterrence belief seems persuasive. Table 1, for instance, shows that Denmark has roughly half the gun ownership rate of neighboring (across the Baltic) Norway, but a one third higher murder rate; and Russia, another neighbor of Norway, has only one ninth Norway's gun ownership rate but a 900\% higher murder rate. Looking at tables 1-3 it is easy to find nations in which very high gun ownership rates correlate with very low murder rates while other nations with very low gun ownership rates have much higher murder rates. And in various nations discussed in this article drastic reductions in gun ownership among the law-abiding populace have coincided with substantial increases in murder or violent crime in general.

Moreover there is not insubstantial evidence that in the United States widespread gun

ethical or moral objections to civilian self-defense are presented in the guise of empirical argument. The empirical evidence unquestionably establishes that gun ownership by prospective victims both allows them to resist criminal attack and deters violent criminals from attacking in the first place. See the results of U.S. Justice Departmentfunded surveys among large numbers of incarcerated adult and juvenile felons in James D. Wright \& Peter Rossi, ARMED AND DANGEROUS: A SURVEY OF FELONS AND THEIR FIREARMS 154 (1986) and Joseph F. Sheley \& James D. Wright, IN THE LINE OF FIRE: YOUTH, GUNS AND VIOLENCE IN URBAN AMERICA 63 (Aldine, 1995), as well as the evidence reported in, for instance, Lawrence Southwick, "Self-Defense with Guns: The Consequences," 28 J. CRIM. JUSTICE 351-370 (2000) David B. Kopel, "Lawyers, Guns and Burglars," 43 ARIZONA LAW REV. 346-367 (2001) and John R. Lott, THE BIAS AGAINST GUNS (2003).

The legitimate question is not whether victim gun possession allows for self-defense and deters criminal violence, but how extensive and important these benefits are. Compare Kleck \& Kates, supra, chs. 6 and 7, Philip J. Cook \& Jens Ludwig, GUNS IN AMERICA (1997), Philip J. Cook \& Jens Ludwig, "Defensive Gun Use: New 
availability has helped reduce murder and other violent crime rates. But on closer analysis this evidence is uniquely applicable to the U.S., and inapplicable to other nations.

More than 100 million handguns are owned in the U.S. ${ }^{69}$, primarily for self-defense ${ }^{70}-$ and 3.5 million people have permits to carry concealed handguns for protection ${ }^{71}$. The latest analysis reveals "a great deal of self-defensive gun use" in the U.S., "in fact, more defensive gun uses [by victims] than crimes committed with firearms ${ }^{72}$." It is little wonder that National Institute of Justice surveys among prison inmates find large percentages saying fear that a victim might be armed deterred them from confrontation crimes. '[T]he felons most frightened "about confronting an armed victim" were those from states with the greatest relative number of privately owned firearms.' Conversely, robbery is highest in states that most restrict gun ownership." ${ }^{73}$

Concomitantly a series of studies by John Lott and his co-author David Mustard conclude that the issuance of millions of permits to carry concealed handguns are associated with drastic declines American homicide rates ${ }^{74}$.

Evidence from a National Survey," 14 J. QUANT. CRIMIN. 111 (1998), Lott, MORE GUNS, LESS CRIME, supra, and Marvin E. Wolfgang, "A Tribute to a View I Have Opposed", 86 J. CRIM. L. \& CRIMINOL, 188 (1995).

${ }^{69}$ See figures given at p. 63 of Don B. Kates, "The Limits of Gun Control: A Criminological Perspective" in Timothy Lytton, ed., SUING THE FIREARMS INDUSTRY: A LEGAL BATTLE AT THE CROSSROADS OF GUN CONTROL AND MASS TORTS (Ann Arbor, University of Michigan Press, 2005).

${ }^{70}$ Gary Kleck, TARGETING GUNS: FIREARMS AND THEIR CONTROL 74 (1997) collecting survey responses.

${ }^{71}$ Kates, supra, at p. 65.

${ }^{72}$ James B. Jacobs, CAN GUN CONTROL WORK 14 (Oxford, Oxford U. Press, 2002), collecting studies.

${ }^{73}$ Kates supra at p. 70 collecting studies.

${ }^{74}$ John R. Lott Jr. \& David B. Mustard, "Crime, Deterrence, and Right-to-Carry Concealed Handguns,” 26 JOURNAL OF LEGAL STUDIES 1-68 (1997), John R. Lott Jr., MORE GUNS, LESS CRIME:

UNDERSTANDING CRIME AND GUN CONTROL LAW (U. Chicago Press, 1998), David B. Mustard, "Culture Affects Our Beliefs About Firearms, But Data Are Also Important," 151 U. PENN. L. REV. 1387 (2003). These studies are highly controversial. See Kates, supra, 70-71 for discussion of critics and criticisms. 
Ironically, to detail the American evidence for the deterrent value of widespread defensive gun ownership is also to raise questions as to how applicable that evidence would be to even those other nations that have widespread gun ownership but low violence. There are no data for foreign nations comparable to the U.S. data just discussed. Without such data are we to believe millions of Norwegians own handguns and carry them for protection, wherefore Norwegian criminals are deterred from committing violent crimes? Or that guns are commonly kept for defense in German homes and stores so German criminals are afraid to rob them? On the contrary it seems unlikely that guns are commonly owned for protection in nations whose violence rates are so low.

Moreover, if the deterrent effect of gun ownership accounts for low violence rates in high gun ownership nations other than the U.S., one has to wonder why that deterrent effect is so much greater there. Even with the drop in U.S. murder rates which Lott and Mustard attribute to the massive increase in gun carry licensing, the U.S. murder rate is still eight times higher than Norway's - despite the fact that the U.S. has an almost $300 \%$ higher rate of gun ownership. That is consistent with the points made above: Murder rates are determined by socio-economic and cultural factors. In the U.S. those factors include that the number of civilian-owned guns nearly equals the population - triple the ownership rate in even the highest European gun-ownership nations - and, that vast numbers of guns are kept for personal defense. That is not a factor in other nations with comparatively high firearm ownership. High gun ownership may well be a factor in the recent drastic decline in American homicide. But even so American homicide is driven by socio-economic and cultural factors which keep it far higher than in most European nations.

In sum, though many nations with widespread gun ownership have much lower murder rates than nations that severely restrict gun ownership, it would be simplistic to assume that at all 
times and in all places widespread gun ownership depresses violence by deterring many criminals into non-confrontation crime. There is evidence that it does so in the U.S. where defensive gun ownership is a substantial socio-cultural phenomenon. But the more plausible explanation for many nations having widespread gun ownership with low violence is that these nations never had high murder and violence rates and so never had occasion to enact severe anti-gun laws. On the other hand in nations that have experienced high and rising violent crime rates, the legislative reaction has generally been to enact increasingly severe anti-gun laws. This is futile for reducing gun ownership by the law-abiding citizenry - the only ones who obey gun laws - does not reduce violence or murder. The result is that high crime nations that ban guns to reduce crime end up having both high crime and stringent gun laws, while low crime nations which do not much restrict guns continue to have low violence rates.

Thus we believe that both sides of the gun prohibition debate are wrong in seeing the availability of guns as a major determinative factor in the incidence of murder in any particular society. We recognize, however, that many people believe that gun availability has great importance in explaining homicide rates. To those who prefer that belief we offer an admonition based on the historical, geographic, and demographic evidence explored in this article. Whether gun availability be viewed as a cause or as a mere coincidence, the long term macrocosmic evidence is that gun ownership spread widely throughout societies consistently correlates with stable or declining murder rates. This pattern simply cannot be squared with the mantra that more guns $=$ more death and fewer guns $=$ less. Whether causative or not, the consistent international pattern is that more guns = lessmurder and other violent crime. Wenow proceed to further examine that consistent international pattern. Even if one is inclined to think that gun availability 
is an important factor the available international data cannot be squared with the mantra that more guns $=$ more death and fewer guns $=$ less. Rather, if firearms availability does matter, the data consistently show that the way it matters is that more guns $=$ lessviolent crime.

\section{GEOGRAPHIC, HISTORICAL AND DEMOGRAPHIC PATTERNS}

If more guns $=$ more death and fewer guns $=$ less death it should follow, ceteris paribus: a) that geographic areas with higher gun ownership should have more murder than those with less gun ownership; b) that demographic groups with higher gun ownership should be more prone to murder than those with less ownership; and c) that historical eras in which gun ownership is widespread should have more murder than those in which guns were fewer or less widespread. As discussed infra, these effects which should follow - if more guns really do mean more death - do not follow. Historical eras, demographic groups and geographic areas with more guns do not have more murder than those with fewer. Indeed, those with more guns often or even generally, have less murder.

Of course, all other things may not be equal. Obviously, many factors other than guns may promote or reduce the numbers of murders in any given place or time, or among particular groups. And it may be impossible even to identify these factors, much less to take account of them all. Thus any conclusion to be drawn from the kinds of evidence that are presented infra must necessarily be tentative.

Acknowledging this does not, however, blunt the force of two crucial things. The first is the burden of proof. Those who assert the mantra, and urge that public policy be based on it, bear 
the burden of proving that more guns do = more death and fewer guns = less death. But they cannot bear that burden because there simply are no large number of cases in which the prevalence of guns among the general population has led to more murder. By the same token, but even more important, it cannot be shown that in many cases a reduction in the number of guns available to the general population has led to less death. Nor is the burden borne by speculating that the reason such cases do not appear is that other factor(s) always intervene so it turns out that more guns don't mean more death and/or that fewer do not mean less death.

Allied to the burden of proof issue is that of plausibility. On their face the following facts from Table 2 supra suggest that gun ownership is irrelevant, or has little relevance, to murder: France and neighboring Germany have exactly the same (comparatively high) rate of gun ownership, yet the French murder rate is nearly twice the German; France has infinitely more gun ownership than Luxembourg which nevertheless has a five times higher murder rate though handguns are illegal and other kinds of guns sparse; Germany has almost double the gun ownership rate of neighboring Austria, yet much the same (very low) murder rate; the Norwegian gun ownership rate is over twice the Austrian yet the murder rates are almost identical.

And then there is Table 3 which shows, inter alia: Slovenia with $40 \%$ more gun ownership than Slovakia nevertheless has roughly 1/3rd less murder per capita; Hungary has more than six and half times the gun ownership rate of neighboring Roumania but a substantially lower murder rate; the Czech Republic's gun ownership rate is more than 3 times that of neighboring Poland but its murder rate is lower; Poland and neighboring Slovenia have exactly the same murder rate though Slovenia has over three times more gun ownership per capita. 


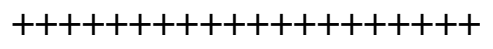

Table 3 about here

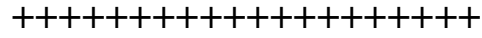

On their face Tables 2 and 3, and the comparisons gleaned from them suggest that gun ownership is irrelevant, or has little relevance, to murder. So, as will be seen, do the historical and demographic comparisons discussed infra. Again, all these data may be misleading. It is conceivable that more guns do $=$ more murder, but that this causation does not appear because some unidentifiable extraneous factor(s) always intervene so that geographic areas, demographic groups and historical eras with more guns nevertheless have no more murder than those with fewer guns. That is conceivable, but is it likely? In the words of, Hans Toch, a senior American criminologist who 35 years ago endorsed handgun prohibition and confiscation, but then recanted based on later research: "It is hard to explain that where firearms are most dense, violent crime rates are lowest, and where guns are least dense violent crime rates are highest."75

Prof. Toch had been a consultant to the 1960s Eisenhower Commission, and until the 1990s had endorsed its conclusions that widespread handgun ownership causes violence, and that reducing it would reduce violence. Franklin Zimring, one of the architects of those conclusions, has admitted that they were made speculatively, and essentially without empirical basis. ${ }^{76}$ As to

\footnotetext{
${ }^{75}$ Quoting from HansToch \& Alan Lizotte, "Research and Policy: The Case of Gun Control" in PSYCHOLOGY AND SOCIAL POLICY, edited by Peter Sutfeld and Philip Tetlock (NY Hemisphere, 1992).

${ }^{76}$ Franklin E. Zimring \& Gordon Hawkins, THE CITIZEN'S GUIDE TO GUN CONTROL 32 (1987): "In the 1960s after the assassinations of President John F. Kennedy, Dr. Martin Luther King and Senator Robert F. Kennedy, it [gun control] became a major subject of public passion and controversy, [sparking a debate that] has been heated, acrimonious and polarized... It began in a factual vacuum [in which] neither side felt any great need for factual support to buttress foregone conclusions. In the 1960s, there was literally no scholarship on the relationship between guns and the incidence or consequences of interpersonal violence and no work in progress." Emphasis added.
} 
the findings of the subsequent corpus of research, Toch has written:

[W]hen used for protection firearms can seriously inhibit aggression and can provide a psychological buffer against the fear of crime. Furthermore, the fact that national patterns show little violent crime where guns are most dense implies that guns do not elicit aggression in any meaningful way. Quite the contrary, these findings suggest that high saturations of guns in places, or something correlated with that condition, inhibit illegal aggression. ${ }^{77}$

\section{DEMOGRAPHIC PATTERNS}

Contrary to what should be the case if more guns = more death, there are no "consistent indications of a link between gun ownership and criminal or violent behavior by owners"; in fact, gun ownership is "higher among whites than among blacks, higher among middle-aged people than among young people, higher among married than among unmarried people, higher among richer people than poor" - these all being "patterns that are the reverse of the way in which criminal behavior is distributed. ${ }^{78,}$

These conclusions are reinforced by focus on patterns of Afro-American homicide. Per capita, Afro-American murder rates are much higher than white. ${ }^{79}$ If more guns $=$ more death, and fewer guns = less, one might assume gun ownership is higher among Afro-Americans than among

\footnotetext{
77 Toch \& Lizotte, supra, at pp. 232, 234.

${ }^{78}$ Kleck, TARGETING GUNS, p. 71

${ }^{79}$ Malcolm, GUNS AND VIOLENCE: THE ENGLISH EXPERIENCE, supra, 232-33, Alfred Blumstein, "Youth Violence, Guns and the Illicit-Drug Industry," 86 J. CRIM L. \& CRIMINOL. 10, 21 (1995).
} 
whites. But, no, Afro-American gun ownership is markedly lower than white. ${ }^{80}$

Particularly corrosive to the mantra is the major exception to the fact that Afro-Americans have lower gun ownership: per capita: Rural Afro-Americans are much, much more likely to have firearms, than are urban Afro-Americans. ${ }^{81}$ Yet, despite their generally much greater access to guns, the murder rate of young rural black males is a small fraction of the murder rate of young urban black males. ${ }^{82}$

These facts are only anomalous in relation to the mantra more guns = more death/fewer guns = less. In contrast, these facts accord with, indeed exemplify, the point of our earlier discussion of the aberrance of murderers: Whatever their race, ordinary people simply do not murder. So it does nothing at all to reduce murder that law abiding, responsible Afro-Americans have fewer guns -- because they aren't the ones who are killing. The killers are a small minority of extreme anti-social aberrants who manage to get guns whatever the level of gun ownership in the black community generally.

Indeed, murderers generally fall into a group some criminologists have called "violent predators," sharply differentiating them not only from the overall population but from other criminals as well. Surveys among imprisoned felons indicate that while on the outside the ordinary felon averages perhaps 12 crimes per year. In contrast, "violent predator"-type felons spend much or most of their time committing crimes, averaging 8 assaults, 63 robberies, 172

80 "... white gun ownership exceed[ed] that for blacks by about 40 percent in 1996..." John R. Lott, MORE GUNS, LESS CRIME 39 (Chicago, U. of Chicago: 2000). See generally Kleck, TARGETING GUNS, supra, p. 71.

${ }^{81} \mathrm{Id}$.

${ }^{82}$ The murder rate of young urban Afro-Americans is roughly 1,000\% higher than that of their rural counterparts. See Lois A. Fingerhut, et al., "Firearm and Non Firearm Homicide Among Persons 15 Through 19 Years of Age," JOURNAL OF THE AMERICAN MEDICAL ASSOCIATION 267 (1992): 3048 at 3049 , table 1 
burglaries, and 214 other thefts annually. ${ }^{83}$ A National Institute of Justice survey among 2,000 felons in ten state prisons which focused on gun crime said of these types of respondents: ...the men we have labeled Predators were clearly omnibus felons ... committ[ing] more or less any crime they had the opportunity to commit... [T] The Predators (handgun and shotgun combined) amounted to about $21 \%$ of the sample and yet accounted for $51 \%$ of the total crimes [admitted by the 2,000 felons]... Thus when we talk about controlling crime in the United States today, we are talking largely about controlling the behavior of these men. ${ }^{84}$

The point here is not just that demographic patterns of homicide and gun ownership in the Afro-American community do not support the more guns = more death mantra. More important yet is those patterns' refutation of fewer guns = less death. The fact of fewer guns among ordinary Afro-Americans does not lead to fewer murders for it does not mean fewer guns for the aberrant minority who murder. The correlation of very high murder rates with low gun ownership in AfroAmerican communities in general simply does not bear out the notion that disarming the populace as a whole will disarm, and prevent murder by, the potential murderers,

\section{MACRO-HISTORICAL EVIDENCE: From Medieval Times to the $20^{\text {th }}$ Century.}

Notoriously, the Dark Ages were a time of brutal and endemic warfare. They also experienced rates of ordinary murder about double those of the U.S. at its worst. But Dark Age homicide "cannot be explained in terms of the availability of firearms, which had not yet been

\footnotetext{
${ }^{83}$ Jan M. Chaiken \& Marcia R. Chaiken, VARIETIES OF CRIMINAL BEHAVIOR (Rand, 1982).

${ }^{84}$ ARMED AND CONSIDERED DANGEROUS, supra. 76.
} 
invented." 85 But that invention itself provides some test of the mantra. If it were true that more guns $=$ more murder/fewer guns $=$ less death, murder should have risen with the invention of firearms and their becoming ever more efficient and more widely distributed among the population.

Yet murder rates seem to have fallen sharply as guns became more efficient and widely owned in England, much of Europe and Scandinavia over the five centuries after the invention of firearms ${ }^{86}$ During much of this period, incidentally, because the entire adult male population of England was deemed to constitute a militia, every military age male was required to possess arms and appear with them when called out for militia training and actual service. ${ }^{87}$

The same was true in America during the period of colonial and post-colonial settlement. Indeed the basic English militia laws were superceded by the colonies' even more specific and demanding legal requirements of universal gun ownership. Under those laws virtually all colonists, and every home, had to have guns. By law, male youths were deemed of military age at 16, 17 or 18 (depending on the colony) and every military age man, excepting the insane, infirm, and criminals, had to have arms; and they were subject to being called for inspection, militia drill or service bringing their legally required guns. To arm those too poor to afford guns, the laws required that guns be purchased for them and that they would have to make installment payments

${ }^{85}$ Lane, supra, MURDER IN AMERICA p. 15 and ch. 1 generally.

${ }^{86}$ Ibid., p. 20, Malcolm, GUNS AND VIOLENCE: THE ENGLISH EXPERIENCE, supra, pp. 19-20.

${ }^{87}$ See generally Joyce Lee Malcolm, TO KEEP AND BEAR ARMS: THE ORIGINS OF AN ANGLOAMERICAN RIGHT ch. 1 (Cambridge, Harvard, 1994), Stephen P. Halbrook, "THAT EVERY MAN BE ARMED": THE EVOLUTION OF A CONSTITUTIONAL RIGHT ch. 2 (Albuquerque, U. Of N.M. Press: 1984) and Don B. Kates, "Handgun Prohibition and the Original Meaning of the Second Amendment", 82 MICH. L. REV. 203, 214-215 (1983) (hereinafter cited as "Original Meaning”). 
to pay back the cost. ${ }^{88}$

It bears emphasis that these gun ownership requirements were not limited to those subject

to militia service. Women, seamen, clergy, and some public officials were automatically exempt

from militia call up, as were men over the upper military age which varied from 45 to 60 ,

depending on the colony. But, as a deterrent to criminal and other attack, every household was

required to have a gun, even if its occupants were all female, under or overage males, seamen,

clergymen and/or public officials. Likewise, all respectable men were theoretically required to

carry arms when out and abroad. ${ }^{89}$

These laws may have been less fully enforced (except in times of danger) in areas that

${ }^{88}$ Malcolm, TO KEEP AND BEAR ARMS, supra at 138-140, Original Meaning, supra, 82 MICH L. REV. supra, 214-216. Typical laws (quoted with original spelling and punctuation) appear from the following sources: William Hand Browne, ed., ARCHIVES OF MARYLAND (Baltimore: Maryland Historical Society, 1885) 1:77 ("that every house keeper or housekeepers within this Province shall have ready continually upon all occasions within his her or their house for him or themselves and for every person within his her or their house able to bear armes one Serviceable fixed gunne of bastard muskett boare $1 / 4$ " along with a pound of gunpowder, four pounds of pistol or musket shot, "match for matchlocks and of flints for firelocks1/4."); August 2, 1619, "Proceedings of the Virginia Assembly, 1619," in Lyon Gardiner Tyler, NARRATIVES OF EARLY VIRGINIA, 1606-1625 (New York: Charles Scribner's Sons, 1907; reprinted New York: Barnes \& Noble, 1959), 273. (requiring that everyone attend church on Sunday, further providing that "all such as bear arms [i.e., all able-bodied males aged 16 and above] shall bring their pieces, swords, powder and shot" with them to church on penalty of a fine.); Nathaniel B. Shurtleff, RECORDS OF THE GOVERNOR AND COMPANY OF THE MASSACHUSETTS BAY IN NEW ENGLAND (Boston: William White, 1853) 1:83 (requiring that everyone, including servants, was to be armed -- with anyone unable to afford a gun to be armed by the town, which the recipients were to reimburse "when they shal be able."); John Russell Bartlett, ed., RECORDS OF THE COLONY OF RHODE ISLAND AND PROVIDENCE PLANTATIONS, IN NEW ENGLAND (Providence, R.I.: A. Crawford Greene and Brother, 1856), 1:79-80 and 1:94 (requiring, respectively:: "that every man do come armed unto the meeting upon every sixth day," and also that militia officers go "to every inhabitant [in Portsmouth and] see whether every one of them has powder" and bullets; and "that noe man shall go two miles from the Towne unarmed, eyther with Gunn or Sword; and that none shall come to any public Meeting without his weapon."); CODE OF 1650, BEING A COMPILATION OF THE EARLIEST LAWS AND ORDERS OF THE GENERAL COURT OF CONNECTICUT (Hartford, Conn.: Silas Andrus, 1822), $72-73$ ("That all persons that are above the age of sixteene yeares, except magistrates and church officers, shall beare arms...; and every male person with this jurisdiction, above the said age, shall have in continuall readines, a good muskitt or other gunn, fitt for service, and allowed by the clark of the band. $1 / 4 "$ ).

${ }^{89}$ See sources cited in last footnote. For collections of many of the relevant laws see: http://www.claytoncramer.com/GunControlColonialNewEngland.PDF, http://www.claytoncramer.com/GunControlColonialNewEngland2.PDF, http://www.claytoncramer.com/MiddleSouthernColonialGunControl.PDF and 
had been long settled and peaceful. Nevertheless "by the eighteenth century colonial Americans were the most heavily armed people in the world." 90 Yet, far from more guns meaning more death, murders were "rare" and "few" involved guns "despite their wide availability."91

America remained very well armed, yet homicide remained quite low, for over two hundred years from the earliest settlements through the entire colonial and early Republic periods. Homicide only began rising markedly in the two decades before the Civil War. ${ }^{92}$ By that time the universal militia was inoperative and the universality of American gun ownership had disappeared as many people in long-settled peaceful areas did not hunt and had no other need for a firearm. $^{93}$

Then came the Civil War which acquainted vast numbers of men with modern rapid-fire guns and then, in its aftermath, provided a unique opportunity to acquire them. Before the Civil War reliable multi-shot rifles or shotguns did not exist and revolvers (though they had been

http://www.claytoncramer.com/primary.html\#MilitiaLaws.

90 John M. Dederer, WAR IN AMERICA TO 1775 (N.Y., 1990) 116. N.B.: It should be noted that the foregoing facts are contradictory to assertions made in Michael Bellesiles, ARMING AMERICA: THE ORIGINS OF A NATIONAL GUN CULTURE (New York: Alfred A. Knopf, 2000). That book, which won the Bancroft Prize, deemed the premier award for a work of American history, is, unfortunately, still to be found in many libraries, especially university libraries. That book, however, has been discovered to be a fraud; the Bancroft Prize has been withdrawn, the author has found it necessary to resign from his former university and is now reported to be considering a future in high school teaching. "Prize for Book Is Taken Back From Historian," THE NEW YORK TIMES, December 14, 2002 [Section C; Business/Financial Desk; Page 4, Byline: Robert F. Worth]; “The disarming of a bogus scholar" ORANGE COUNTY REGISTER, Nov. 24, 2002 by Alan Bock.; James Lindgren, "Fall From Grace: 'Arming America' and the Bellesiles Scandal", 111 YALE LAW JOURNAL, 2195-2249 (2002); James Lindgren \& Justin Heather, "Counting Guns in Early America", 43_WM. \& MARY L. REV., 1777-1842 (2002).

${ }^{91}$ Lane, MURDER IN AMERICA supra, pp. 48 and 59-60.

${ }^{92}$ Id. $107,344$.

93 The enthusiasm modern gun advocates express for the ancient militia far exceeds the enthusiasm felt by the Englishmen and Americans who were actually subject to the obligations involved. Guns were expensive items even for those owners who were supplied them by the colonies since the cost was required to be paid back over time. And the duty of militia drill was a constant source of irritation to men who had little time for leisure and urgent need to devote their time to making a living for themselves and their families. By the turn of the Nineteenth Century at the earliest the universal militia was in desuetude replaced in the 1840s by colorfully garbed volunteer formations whose 
invented in the 1830s) were so expensive as to be effectively out of reach to most of the American populace. ${ }^{94}$ The Civil War changed all that. Officers on both sides had to buy their own revolvers and side arms were issued to non-commissioned officers generally, and also to those ordinary soldiers who were in the artillery, cavalry and dragoons. ${ }^{95}$ How many revolvers this involved is suggested by the fact that in all over two million men served in the Civil War U.S. Army at various times while the Confederates had over half that number. ${ }^{96}$

At war's end the U.S. Army and Navy were left with vast numbers of surplus revolvers, both those they had purchased and those captured from Confederate forces. As the Army

activities were far more social than military.

${ }^{94}$ Due to lack of sales Colt went bankrupt in 1840. It revived only with sales to officers and the military during the Mexican-American War (1846-48), and was sustained through the 1850s by sales to wealthy Americans and Europeans. See generally, Joseph G. Bilby, CIVIL WAR FIREARMS: THEIR HISTORICAL BACKGROUND, TACTICAL USE AND MODERN COLLECTING AND SHOOTING 157 (1996), Lee Kennett \& James LaVerne Anderson, THE GUN IN AMERICA: THE ORIGINS OF A NATIONAL DILEMMA (London, Greenwood, 1975) at 90, Lane, MURDER IN AMERICA, 109. Colt's sales flourished as his revolver was adopted by foreign armies and was widely sold to officers and the wealthy in England and Europe (ibid.), especially after Colt's prize-winning exhibit at the 1851 Great Industrial Exhibition in London. Joseph. G. Rosa, COLONEL COLT LONDON (Arms \& Armour Press, 1976), ch. 1 (Colt and the Great Exhibit).

${ }^{95}$ See generally CIVIL WAR FIREARMS, supra, ch. V. The revolvers involved were by no means all Colts: "the Federal government also purchased large numbers of Remington, Starr and Whitney revolvers, as well as the guns of other [American] makers, including the bizarre looking Savage with its second 'ring trigger' which cocked the arm, and the sidehammer Joslyn." Id. at 158. Vast numbers were also purchased in Europe where, in the first 15 months of the war, the Union bought over 738,000 firearms (including long arms as well as revolvers). Allan R. Miller \& Peter Maslowski, FOR THE COMMON DEFENSE: A MILITARY HISTORY OF THE UNITED STATES 217 (N.Y. Free Press, 1984). In addition to cavalry, dragoon and artillery units, some Union infantry units were issued revolvers and many enlisted infantrymen in other units bought their own.

Confederate cavalry were sometimes armed with older-pattern double-barrelled pistols, or even shotguns, for lack of revolvers. Colt sold revolvers to the South (until forbidden to do so), and the Confederacy manufactured its own revolvers and purchased as many as possible from European sources. $\underline{\text { Id. }}$.

${ }^{96}$ These are just estimates. While for the Union Army at least somewhat reliable figures exist for how many served at any one time (see next footnote), that number is not co-extensive with how many served in total. Some Union soldiers served throughout the war, re-enlisting when their original enlistments were up. Others mustered out, being replaced with new recruits. Others yet deserted long before their terms were up, again requiring replacements. Some scoundrels enlisted just for the enlistment bonus, and deserted as soon as they could; some of these went through the enlistment-then desertion process multiple times, collecting a new bonus under a new name time after time. THE WORLD ALMANAC (1986) p. 333 gives a figure of 2,128,948 for the Union Army, 84,415 for the Marines and estimates the Confederate Army at 600,000 to 1.5 million. 
plummeted to slightly over 11,000 men, ${ }^{97}$ hundreds of thousands of military surplus revolvers were sold to jobbers at rock bottom prices. In addition, of course, when their enlistments were up, or when they were mustered out at war's end, former officers and soldiers had walked off with hundreds of thousands of both revolvers and rifles. This included many of the new repeating rifles the Union had bought (over the fervent objections of short-sighted military procurement officers) at the command of President Lincoln who had tested the Spencer rifle himself. After his death the Army reverted to the single-shot rifle, disposing of all its multi-shots at surplus, thereby ruining Spencer by glutting the market. ${ }^{98}$

Thus over the immediate post-Civil War years "the country was awash with military pistols" and rifles of the most modern design. ${ }^{99}$ And the next decade through the end of the Century saw the introduction and marketing of the "two dollar pistol" (as in "hotter than"). These were very cheap handguns manufactured largely out of pot metal. Besides being sold locally such "Suicide Specials" were sold nationwide through Montgomery Ward catalogs from 1872 on and by Sears from 1886 . They were priced as low as $\$ 1.69$, and were marketed under names like the "Little Giant" and the "Tramp's Terror." 100

Thus the period 1866-1900 saw a vast diffusion of commercial and military surplus

\footnotetext{
97 "The names of 1,000,516 officers and men were on the [U.S. Army's] roles on May 10, 1865; by [1866, the draft had ended and] .... only 11,043 volunteers remained...." Russell F. Weighley, HISTORY OF THE UNITED STATES ARMY 262 (N.Y. Macmillan, 1967).

${ }^{98}$ Kennett \& Anderson, supra, at 92-93.

${ }^{99}$ David T. Courtwright, VIOLENT LAND: SINGLE MEN AND SOCIAL DISORDER FROM THE FRONTIER TO THE INNER CITY (Harvard U. Press, 1996) at 42.

${ }^{100}$ Kennett \& Anderson, supra, pp. 98-100. SCIENTIFIC AMERICAN, June 14, 1879, p. 381 contains an advertisement for COD purchasing of the \$2.50 "Czar" revolver, presumably an attempt to capitalize on the S\&W "Russian", a very high quality weapon S\&W manufactured for the Russian government and sold through the 1870 s. The 1884 Price List-Firearms Catalog for N. Curry \& Brother, arms dealers of San Francisco, lists prices from $\$ 2.00$ for the 7 shot "Fashion" and Blue Jacket" revolvers to $\$ 2.50$ and $\$ 3.50$ for the "Kitemaug" and "Ranger" revolvers to
} 
revolvers and lever action rifles throughout the American populace. Yet, far from rising, homicide seems to have fallen off sharply from the 1870s through the end of the 19th Century.

\section{SUMMARY OF MACRO-HISTORICAL EVIDENCE FROM THE DARK AGES TO THE 20th}

\section{CENTURY}

Whether or not guns were the cause, homicide steadily declined over a period of five centuries coincident with their invention and diffusion throughout the continent. From the 17 th through the early 19th Centuries in America murder was rare, and rarely involved guns, though gun ownership was universal by law and "colonial Americans were the most heavily armed people in the world." By the 1840s gun ownership had declined but homicide began a spectacular rise through the early 1860 s. From the end of the Civil War to the turning of the 20th Century America experienced a tremendous spurt in ownership of higher capacity revolvers and rifles than had ever previously existed but murder sharply declined. ${ }^{101}$

In sum, more guns = more death is not borne out by the historical evidence available for the period of the Middle Ages to the $20^{\text {th }}$ Century. Yet this must be viewed with caution. While one may describe broad general trends in murder rates and in the availability of firearms, it is not possible to do so with exactitude before recent times. Not until the late 19th Century in England, and the mid-20th Century in the U.S. are there detailed data on homicide, and information about the distribution of firearms is even more sparse. For instance, Lane's generalizations about the

${ }^{101}$ Lane, MURDER IN AMERICA, supra, pp. 155, 181, 307, Eric Monkkonen, MURDER IN NEW YORK CITY (Berkeley, U.C., 2001). 
rarity of gun murder and low American murder rates in general are subject to some dispute. Roth has shown that early American murder rates and the extent to which guns were used in murder varied greatly between differing areas and time periods. ${ }^{102}$

\section{LATER AND MORE SPECIFIC MACRO-HISTORICAL EVIDENCE.}

Malcolm presents reliable trend data on both gun ownership and crime in England for the period 1871-1964. Significantly, these trend data do not at all correlate as the mantra would predict: Violent crime did not increase with increased gun ownership nor did it decline in periods in which gun ownership was lower. ${ }^{103}$

In the U.S. a decade from the mid-1960s to the mid-'70s saw the murder rate double. The fact that this coincided with vastly increasing gun sales was taken by many as proof positive that more guns $=$ more death. That, however, did not at all follow. It was at least equally possible that the causation was reversed, i.e., that the decade's spectacular increases in murder, burglary and all kinds of violent crimes caused fearful people to buy guns. ${ }^{104}$ The dubiousness of blithely assuming that the gun sales caused the rise in murder rather than the reverse might have been clearer had it been known in the 1960s- '70s that virtually the same murder rate increase was

\footnotetext{
${ }^{102}$ Randolph Roth, "Guns, Gun Culture, and Homicide," WM \& M. Q., v. 59, pp. 222-240, at 234-40.

${ }^{103}$ These data are discussed in the appendix to her GUNS AND VIOLENCE: THE ENGLISH
} EXPERIENCE. The handgun ownership data are tax data and so doubtless fail to count the pistols owned by criminals and others who failed to pay taxes. But the extremely low numbers of gun crimes do not support the notion that there were numerous criminal owners of guns, or at least that they used the guns for crime.

${ }^{104}$ In contrast to the controversiality of the mantra that more guns = more death, there is ample evidence, and no disagreement, that crime rate increases do fuel gun buying. See, e.g., Douglas C. Rice \& David D. Hemley, "The Market for New Handguns," 45 J. LAW \& ECON. 251 (2002), Lawrence Southwick, "Do Guns Cause Crime? Does Crime Cause Guns? A Granger Test," 25 ATLANTIC ECONOMIC J. 256 (1997) and studies discussed in Kleck, TARGETING GUNS, supra at 79-81. 
occurring in gun-less Russia. ${ }^{105}$ Clearly there was no basis to assume guns were the reason for the American murder rate rise when the Russian murder rate exhibited the same increase, yet virtually none of those murders involved guns.

Reliable information on both gun ownership and murder rates in the U.S are available only for the period from the end of WWII on. Significantly, the decade from the mid- "60s to the mid70 s is a unique exception to the general pattern. That pattern is that, decade-by-decade, the number of guns owned by civilians has risen steadily and dramatically - but murder rates nevertheless remained stable or even declined. As for the second half of the $20^{\text {th }}$ Century, and especially its last quarter, a study comparing the number of guns to murder rates found that over the 25 year period 1973-97 the number of handguns owned by Americans had increased by 163\%, and the number of all firearms by $103 \%$. Yet over that period the murder rate declined by $27.7 \%{ }^{106}$ It continued to decline in the years 1998,1999 and 2000 despite the addition in each year of two-three million handguns, and c. 5 million firearms of all kinds. By the end of the year 2000 the total American gunstock stood at well over 260 million - 951.1 guns for every 1,000 Americans - but the murder rate had returned to the comparatively low level prior to the increases of the mid-‘60s-‘70s period. ${ }^{107}$

In sum, these data for the decades since the end of WWII are further evidence failing to bear out the more guns $=$ more death mantra. These and related data have been summarized as

${ }^{105}$ In 1965 , the Russian homicide rate stood at 5.9 per 100,000 population while the American rate was 5.4. As of 1975 both Russian and American rates had nearly doubled, the Russian to 10.3 and the American to 9.7. Again, we are indebted to Prof. Pridemore for the year-by-year Russian rates from 1965 to 1999, and the fact that very few Russian murders involve guns.

${ }^{106}$ Don B. Kates \& Daniel D. Polsby, "Long Term Non-Relationship of Firearm Availability to Homicide" 4 HOMICIDE STUDIES 185-201 (2000) at 190-91.

${ }^{107}$ We are indebted to Prof. Kleck (personal communication 2/26/2003) for post-1997 sales figures. 
follows:

The per capita accumulated stock of guns (the total of firearms manufactured or imported into the United States, less exports) has increased in recent decades, yet there has been no correspondingly consistent increase in either total or gun violence... About half of the time gun stock increases have been accompanied by violence decreases, and about half the time [they have been] accompanied by violence increases, just what one would expect if gun levels had no net impact on violence rates. ${ }^{108}$

\section{GEOGRAPHIC PATTERNS WITHIN NATIONS}

Once again, if more guns = more death and fewer guns $=$ less death, areas with higher gun ownership should in general have more murder than those with less gun ownership in a single nation. But, in fact, the reverse pattern prevails in Canada, ${ }^{109}$ "England, America and Switzerland, [where the areas] with the highest rates of gun ownership are in fact those with the lowest rates of violence. ${ }^{110}$ A recent study of all counties in the United States has again demonstrated the lack of relationship between the prevalence of firearms and homicide ${ }^{111}$. (1994).

${ }^{108}$ TARGETING GUNS, supra, p. 18, emphasis added

${ }^{109}$ Philip C. Stenning, "Gun Control - A Critique of Current Policy," POLICY OPTIONS, v. 15, p. 15

${ }^{110}$ Joyce Lee Malcolm, GUNS AND VIOLENCE: THE ENGLISH EXPERIENCE (Cambridge, Harvard: 2002); see also BBC News, "Handgun Crime 'Up' Despite Ban," noting that English areas with very low numbers of firearms have higher than average gun crime while areas with the highest levels of legally held guns do not.

${ }^{111}$ Gary Kleck, Kovandzic, Tomislav and Mark E. Schaffer. "Gun Prevalence, Homicide Rates and Causality: A GMM Approach to Endogeneity Bias," CEPR DISCUSSION PAPERS, Number 5357. Centre for 
This inverse correlation (more guns-less crime) is one of several which seem to contradict more guns $=$ more death. To reiterate, for decades the gun control lobby has emphasized that, in general, the American jurisdictions most restrictive of guns have consistently had the highest violent crime rates and those with the fewest restrictions have the lowest violent crime rates. ${ }^{112}$ For instance, robbery is highest in jurisdictions which are most restrictive of gun ownership. ${ }^{113}$ As to one specific control, the ban on carrying concealed weapons $(\mathrm{CCW})$ for protection, "violent crime rates were highest in the states [that flatly ban $\mathrm{CCW}$, next highest in those that allowed local authorities discretion [to deny $\mathrm{CCW}$ ] ... permits, and lowest in states with nondiscretionary" CCW laws under which police are legally required to license every qualified applicant. ${ }^{114}$ Also of interest are the extensive National Institute of Justice-sponsored opinion surveys among incarcerated felons, both juvenile and adult: Large percentages of the felons replied that they often feared potential victims might be armed and aborted violent crimes because of that fear ${ }^{115}-$ and "the felons most frightened 'about confronting an armed victim' were those from states with

Economic Policy Research, London, 2006.

${ }^{112}$ See http://www.nraila.org/FactSheets.asp?- FormMode=Detail\&ID=18

http://www.nraila.org/FactSheets.asp?FormMode=Detail\&ID=17 and

http://www.nraila.org/FactSheets.asp?FormMode=Detail\&ID=73.

${ }^{113}$ Philip J. Cook, "The Effect of Gun Availability on Robbery and Robbery-Murder: A Cross Section Study of 50 Cities" 3 POL. STUD. REV. ANN. 743, 776-778 (1979).

${ }^{114}$ Lott, MORE GUNS, LESS CRIME, supra, p. 43. As a practical matter, where police retained discretion to grant or deny licenses/permits, they often are only issued to celebrities, the very wealthy and others having extraordinary political influence. Permit holders in jurisdictions with discretionary issuance have included Eleanor Roosevelt, Arthur Ochs Sulberger (publisher of the NEW YORK TIMES) William F. Buckley, Donald Trump, various DuPonts and Rockefellers, Dianne Feinstein, and actors Tom Selleck, Sean Penn, and James Caan. See, e.g., Melanie Lefkowitz, Newsday, Sept. 30, 2002, "Cleared to Carry in [New York] City: [Carry] Permit Totals Drop, But Not for Notables." In nondiscretionary states, c. 4-10\% of the adult population apply for licensure and must be granted it upon a showing that they are properly trained and law abiding, regardless of whether they have special influence.

${ }^{115}$ Sheley \& Wright, IN THE LINE OF FIRE and Wright \& Rossi, ARMED AND CONSIDERED DANGEROUS, both supra. 
the greatest relative number of privately owned firearms." 116

\section{GEOGRAPHIC COMPARISONS: EUROPEAN GUN OWNERSHIP AND MURDER RATE}

\section{COMPARISONS}

This topic has already been addressed as some length in connection with Tables 1-3 supra, which contain the latest data available to us. Tables 4-6, which appear at the end of the paper contain further, and somewhat more comprehensive, data from the mid and early $1990 \mathrm{~s} .{ }^{117}$ These further reinforce the point that murder rates are determined by basic socio-cultural and economic factors rather than mere availability of some particular form of weaponry. Consider Norway, its neighbors Sweden, and (across the Baltic and North Seas respectively) Holland and Denmark. Norway has far and away Western Europe's highest household gun ownership (32\%), but also its lowest murder rate. Holland has the lowest gun ownership in Western Europe (1.9\%), and Sweden lies midway between (15.1). Yet the Dutch murder rate is half again higher than the Norwegian, and the Swedish rate is even higher yet, though only slightly. (See Table 5 infra.)

These comparisons are reinforced by Table 6, which gives differently derived (and noncomparable) gun ownership rates, overall murder rates, and rates of gun murder, for a larger set of European nations. ${ }^{118}$ Reference to Table 6 reveals that though Sweden has more than double the rate of gun ownership as neighboring Germany, and more gun murders, it has $25 \%$ less murder

\footnotetext{
${ }^{116}$ Id. at 151.

117 Tables 3-6 were previously published as appendices to Don B. Kates, "The Limits of Gun Control: A Criminological Perspective" in Timothy Lytton, ed., SUING THE FIREARMS INDUSTRY: A LEGAL BATTLE AT THE CROSSROADS OF GUN CONTROL AND MASS TORTS (Ann Arbor, University of Michigan Press, 2005)
} 
overall. In turn, Germany, with three times the gun ownership rate of neighboring Austria as well as a higher gun murder rate, has a substantially lower murder rate overall. Likewise, though Greece has over twice the per capita gun ownership rate of the Czech Republic, Greece has substantially less gun murder - and less than half as much murder overall. Although Spain has over 12 times more gun ownership than Poland, the latter has almost a third more gun murder, and its overall murder rate is almost twice Spain's. And then there is Finland, with 14 times more gun ownership than neighboring Estonia. Yet Estonia's gun murder and overall murder rates are about seven times higher than Finland's.

\section{GEOGRAPHIC COMPARISONS: GUN OWNERSHIP AND SUICIDE RATES}

Though this article devotes much less space to suicide, the mantra more guns = more death/fewer guns = less death is also used to argue that "limiting access to firearms could prevent many suicides." ${ }^{119}$ Once again, this assertion is directly contradicted by the studies of 36 and 21 nations (respectively), which find no statistical relationship: overall suicide rates were no worse in nations with many firearms than in those where firearms were far less widespread. ${ }^{120}$

Consider the data as to European nations in Tables 5 and 6 infra. Sweden with over twice as much gun ownership as neighboring Germany, and 1/3rd more gun suicide, nevertheless has the lower overall suicide rate. Then there is Greece, which has nearly three times more gun

\footnotetext{
${ }^{118}$ Table 6 covers different years than Table 5, its comparative gun ownership figures derive from government records rather than survey data, and it gives rates for gun murders, a datum which is not available in the sources from which Table 5 is taken. See the Explanatory Note which precedes Table 6.

${ }^{119}$ Quoting from Arthur Kellermann et al, "Suicide in the Home in Relation to Gun Ownership" 327 NEW ENGLAND JOURNAL OF MEDICINE 467 (1992); to the same effect see Antoon Leenars, et al. "Controlling the Environment to Prevent Suicide: International Perspectives," 45 CANADIAN J. PSYCHIATRY 633-644 (2000).
} 
ownership than the Czech Republic, and somewhat more gun suicide. Yet the overall Czech suicide rate is $250+\%$ higher than the Greek. Spain has over 12 times more gun ownership than Poland, yet the latter's overall suicide rate is more than double Spain's. Tragically, poor, wretched Finland has over 14 times more gun ownership than neighboring Estonia, and a great deal more gun-related suicide. But how tragic is that for Finland, really, when in fact Estonia turns out to have much the higher suicide rate than Finland overall?

The simple fact is that there is no relationship evident between the extent of suicide and the extent of gun ownership. People do not commit suicide because they have guns available. In the absence of firearms, people who are inclined to suicide just kill themselves some other way. ${ }^{121}$ Two examples seem as pertinent as they are poignant. The first concerns the 1980 s increase in suicide among young American males, an increase that, although relatively modest, inspired perfervid denunciations of gun ownership. ${ }^{122}$ What these denunciamentos failed to mention was

${ }^{120}$ See note 30 supra.

${ }^{121}$ See the thorough review of the issues in ch. 8 of TARGETING GUNS, supra. See also W.H.O.-SMALL ARMS supra. p. 3 showing that around the world "firearms accounted for only one-fifth of all suicides, just ahead of poisoning... [self-] strangulation, i.e. (hanging) was the most frequently used method of suicide."

${ }^{122}$ See, e.g.: J.H. Boyd, "The Increasing Rate of Suicide by Firearms." 308 NEJM 872-874 (1983); J.A. Mercy, et al. "Patterns of Youth Suicide in the United States." 62 EDUCATIONAL HORIZONS 124-127 (1984); CDC, "Youth Suicide in the United States, 1970-1980" (Atlanta: CDC 1986); J.H. Boyd \& Eve K. Moscicki, "Firearms and Youth Suicide", 76 AM. J. PUB. HLTH. 1240 (1986); Deane Calhoun, "From Controversy to Prevention: Building Effective Firearm Policies", INJURY PREVENTION NETWORK NEWSLETTER, Winter, 1989-90 at p. 12; D.M. Endy, et al., "Estimating the Effectiveness of Interventions to Prevent Youth Suicides." 25 MEDICAL CARE S57-S65 (1987); Sloan, Rivara, et al., "Firearms Regulations and Rates of Suicide: A Comparison of Two Metropolitan Areas", 322 NEW. ENG. J. of MED. 369 (1990), James A. Mercy \& Mark Rosenberg, et al., "Public Health Policy for Preventing Violence," 12 HEALTH AFFAIRS 7, 28 (1993); Daniel W. Webster \& Modena E. H. Wilson, "Gun Violence Among Youth and the Pediatrician's Role in Primary Prevention," 94 PEDIATRICS 617, 618ff. (1994) and the following CDC Reports by Lois A. Fingerhut and or Lois A. Fingerhut and Joel C. Kleinman, et al: "Firearm Mortality Among Children and Youth" Advance Data \#178 (CDC National Center for Health Statistics, 1989); "Firearm Mortality Among Children, Youth, and Young Adults 1-34 Years of Age, Trends and Current Status: United States 1979-1988", MONTHLY VITAL STATISTICS REPORT (March 14, 1991) CDC National Center for Health Statistics; and "Firearm Mortality Among Children, Youth, and Young Adults 1-34 Years of Age, Trends and Current Status: United States, 1985-1990", CDC Advance Date No. 231 (March 23, 1993). 
that suicide of teenagers and young adults was increasing throughout the entire industrialized world - regardless of gun availability and often much more rapidly than in the U.S. The only unusual aspect of U.S. suicide was that it involved guns. The irrelevancy of this to the increase in suicide is evident since suicide among English youth actually increased 10 times more with "car exhaust poisoning [being] the method of suicide used most often...." ${ }^{123}$ By omitting such facts the articles blaming guns for increasing American suicide evaded the inconvenience of having to explain exactly what social benefit nations with few guns got from having their youth suicides occur in other ways.

Even more poignant are the suicides of many young Indian women born and raised on the island of Fiji. In general, women are much less likely to commit suicide than are men. ${ }^{124}$ This is true of Fijian women as well, but not of Indian women in the large part of Fiji's population that is of Indian ancestry. As children, these Indian women are raised in more-or-less loving and supportive homes. But upon marriage they are dispersed across the island to remote areas where they live with their husbands' families. These families are not loving to them and are, in fact, often overtly hostile, a situation the husbands do little to mitigate. Indian women on Fiji have a suicide rate nearly as high as that of either Indian or Fijian men, a rate many times greater than that of non-Indian Fijian women. ${ }^{125}$ It also bears emphasis that the overall Fijian suicide rate far exceeds the U.S. rate.

\footnotetext{
${ }^{123}$ Hawton, K., "By their own young hand," BRIT MED J 1992; 6833 (304): 1000. See also "Teenage Deaths Increasing Across Europe", CJ-INTERNATIONAL, Nov. - Dec. 1991, p. 4 (publication of U. of Ill.Chicago; Office of International Criminal Justice). CJ Europe, 1991.

${ }^{124}$ Data posted on the World Health Organization website reveal, for instance, the following suicide rates: American men 18.6 - American women 4.4; Austrian men 29.3 - Austrian women 10.4; Belgian men 31.3 - Belgian women 11.7; Danish men 20.9 - Danish women 8.1.
} 
The method of suicide is particularly significant. Fijian women of Indian ancestry commit suicide without using guns, perhaps because guns are unavailable. About half these women hang themselves. But the other half die (in agony) from consuming the agricultural pesticide paraquat. The recommendation of the author whose article chronicles all this is so myopic as to almost caricature the more guns = more death mindset: To reduce suicide by Indian women, she recommends that the Fijian state stringently control paraquat. ${ }^{126}$ Apparently she thinks decreased access to a horribly agonizing means of death will reconcile these women to a life situation they regard as unendurable. At the risk of belaboring what should be all too obvious, restricting paraquat will not improve the lives of these poor women. It will only reorient them towards hanging, drowning or some other means of suicide.

Guns are just one among numerous available deadly instruments. So banning guns, or making them less available, cannot reduce the amount of suicide. Once again, all it reduces is the number of suicides by firearms. Suicide committed in other ways increases to make up the difference. To reiterate, data from across the world show no relationship between the extent of suicide and the extent of gun ownership. People do not commit suicide because they have guns available. They kill themselves for reasons they deem sufficient, and in the absence of firearms they just kill themselves in some other way.

(The foregoing should not be deemed to address the issue of whether suicide is "rational."

\footnotetext{
${ }^{125}$ Ruth H. Haynes, "Suicide in Fiji: A Preliminary Study," 145 BRIT. J. PSYCHI. 433 (1984).

${ }^{126}$ Ibid. More or less the same situation seems to prevail in the substantially-Indian populated nation of Sri Lanka (formerly Ceylon). It "has one of the highest suicide rates in the world. Suicides are especially frequent among young adults, both male and female. Compared to the U.S., the suicide rate for males in Sri Lanka is nearly four times greater; the female rate is nearly 13 times greater. The most common mode of suicide is ingestion of liquid pesticides." Lawrence R. Berger, "Suicides and Pesticides in Sri Lanka," 78 AM. J. PUB. HLTH. 826 (1988) (emphasis added).
} 
Doubtless many suicides occur for reasons that might seem irrational to other people but perfectly rational to the person actually committing the act. Vincent Van Gogh and Virginia Woolf killed themselves rather than continuing to endure agonizing mental problems which had proven incurable over a period of years. How can anyone who has not endured their pain judge their solution? Given that suicide has been chosen, under a variety of circumstances, for instance by Demosthenes, Hannibal, Cato the Younger, Cleopatra, Castlereagh, Ernest Hemingway, and Robert LaFollette, Jr., observers who have less-than-overwhelming egotism may hesitate before branding it invariably irrational. In any event, the point is that, regardless of whether suicide is rational or irrational, it does not appear to be controllable by so trivial a measure as restricting access to firearms.)

\section{RECENT EXPERIENCE IN BRITISH COMMONWEALTH ${ }^{127}$ NATIONS}

Capping decades of severe restrictions on gun ownership throughout the British Commonwealth, the last half of the $20^{\text {th }}$ century saw several of the countries in the Commonwealth impose Draconian firearm laws, confiscating hundreds of thousands of firearms from owners law abiding enough to turn them in. ${ }^{128}$ Canada brought in universal gun registration and banned small handguns, the United Kingdom banned all handguns, Australia banned semi-

\footnotetext{
${ }^{127}$ The British Commonwealth is a voluntary association of 53 independent and sovereign nations almost all of which were former colonies or territories of Great Britain. http:/www.thecommonwealth.org/

${ }^{128}$ Gary A. Mauser, MISFIRE: FIREARM REGISTRATION IN CANADA (Vancouver, B.C., Fraser Institute: 2001), and Gary A. Mauser, THE FAILED EXPERIMENT: GUN CONTROL AND PUBLIC SAFETY IN CANADA, AUSTRALIA, ENGLAND AND WALES, Vancouver, BC: The Fraser Institute, 2003
} 
automatic firearms, and both the Republic of Ireland ${ }^{129}$ and Jamaica attempted sweeping firearm bans. These gun laws were adopted amid predictions that they would stem violence, but, as we will show here, none of these measures can be shown to have successfully reduced criminal violence, homicide or suicide in any of these countries ${ }^{130}$.

The Commonwealth's experiments in severe gun restriction were quite expensive, although governments have tried to hide these costs. ${ }^{131}$ Canada's experience provides a specially condign lesson. The government that brought in Canada's universal gun registry program in 1995 with a target date of 2001 had estimated its cost at \$2 million and assured the public that it could be implemented by civil servants without diverting Royal Canadian Mounted Police (RCMP) resources from handling crime. In 2003 after repeated postponements the program continued far behind schedule, with its' estimated final cost being \$2 billion and having diverted tens of thousands of hours of RCMP time. In 2002 a political scandal erupted when the Auditor-General of Canada found that program cost already exceeded $\$ 1$ billion dollars but asserted she could not estimate ultimate cost because the Justice Ministry was now refusing to provide her further

\footnotetext{
${ }^{129}$ The Republic of Ireland will be included along with the countries in the British Commonwealth even though Ireland, upon gaining its independence in 1921, declined the invitation to join the Commonwealth. We have done this because of the close historic and geographic association between Ireland and the United Kingdom.

${ }^{130}$ One member of the British Commonwealth bucked this trend. In 1983, New Zealand abandoned its efforts to register rifles and shotguns as the police found it was too costly to operate and rarely useful in catching criminals. For a thorough discussion of crime trends and firearms control in New Zealand, see REVIEW OF FIREARMS CONTROL IN NEW ZEALAND, REPORT OF AN INDEPENDENT INQUIRY COMMISSIONED BY THE MINISTER OF POLICE, June 1997, by Judge T.M. Thorpe, Queen's Printer, Wellington, New Zealand.

${ }^{131}$ The Canadian government considers the cost of the firearm registry a cabinet secret and has to date refused to divulge the complete costs. See Garry Breitkreuz, "Mr. Speaker, in June 1999 the government used the provision for total exclusion of cabinet confidences under section 69 of the Access to Information Act to keep 172 pages of gun registry budget information a state secret." Tuesday, June 13, 2000, HANSARD, http://www.garrybreitkreuz.com/bills.html, and NEWS RELEASE, November 24, 2003, http://www.garrybreitkreuz.com/breitkreuzgpress/guns102.htm
} 
documentation $^{132}$.

One aspect of England's recent experience deserves note, given how often and favorably advocates have compared English gun policy to American over the past 35 years ${ }^{133}$ An often unstated issue in this notoriously emotional debate was the effect of the Warren Court's (and later judicial) restrictions on police powers. Critics of these decisions pointed to soaring American crime rates and argued simplistically that such decisions were a cause, or at least were hampering police in suppressing crime. But to some supporters of these judicial decisions the example of England argued that the solution to crime was to restrict guns not civil liberties. To gun control advocates England, the cradle of our liberties, was a nation made so peaceful by strict gun control that its police did not even need to carry guns. America, it was argued, could attain such a desirable situation by radically reducing gun ownership, preferably by banning and confiscating handguns.

The results discussed earlier contradicted those expectations. On the one hand, despite constant substantially increasing gun ownership, in the 1990s the U.S. saw progressive and

\footnotetext{
132 The Auditor General is circumspect in this passage, but her meaning is clear: "(10.48) In our view, the financial information provided for audit by the Department does not fairly present the cost of the Program to the government. Our initial review found significant shortcomings in the information the Department provided. Consequently we stopped our audit ..." Sheila Fraser, (2002) Office of the Auditor General of Canada. AUDITOR GENERAL REPORTS 2002. CHAPTER 10. DEPARTMENT OF JUSTICE - COSTS OF IMPLEMENTING THE CANADIAN FIREARMS PROGRAM. December 2002, p 1. (http://www.oag-

bvg.gc.ca/domino/reports.nsf/html/02menu_e.html). The Auditor General's comments led to a judicial inquiry and criminal investigations.

${ }^{133}$ See, e.g. Robert Drinan, S.J., "Banning Handguns Would Reduce Crime," reprinted in Tamara Roleff, GUNS \& CRIME at 45-46 (San Diego, Greenhave, 1999), Irwin Bloch, "Gun Control Would Reduce Crime," 197ff, reprinted. in David Bender, WOULD GUN CONTROL REDUCE CRIME (San Diego, Greenhaven: 1989); Nelson "Pete" Shields, GUNS DON'T DIE, PEOPLE DO ch. 4 (N.Y.: Arbor House, 1981); Amitai Etzioni \& Richard Remp, TECHNOLOGICAL SHORTCUTS TO SOCIAL CHANGE 135 ff. (N.Y.: Sage, 1973); Ramsey Clark, CRIME IN AMERICA pp. 86-90 (N.Y., Simon \& Schuster: 1970), Carl Bakal, NO RIGHT TO BEAR ARMS [see numerous index entries under "England"] (N.Y. Paperback Library: 1968), National Coalition to Ban
} 
dramatic reductions in criminal violence. On the other hand, the same period in the United Kingdom saw constant and dramatically increasing violent crime to which England's response was ever-more drastic gun controls including, eventually, banning and confiscating all handguns and many types of long guns. ${ }^{134}$ Nevertheless, to reiterate, criminal violence so continued its rampant increase that by 2000 England surpassed the U.S. to become one of the developed world's most violence-ridden nations.

Ironic though this is, the English governments' desperate responses to the crime crisis are even more so. Predictably ever-heavier penalties are proposed for the ever-increasing crimes involving the guns no one is supposed to have any more. More ominously, since England has no written constitution, the government is able to jettison civil liberties to a far greater extent than anything American critics of the Warren Court ever dreamed of. The accused's privilege to confront witnesses is now circumscribed to allow convictions based on hearsay testimony; and, when juries nevertheless foolishly acquit, the accused can just be retried -- for the privilege against double jeopardy prosecution has been abolished. ${ }^{135}$ Other steps being considered include revising England's censorship laws in the hope that gun crime can be reduced by banning violent movies, videos, video games and rap music. ${ }^{136}$

To conserve the resources of the inundated criminal justice system police no longer

Handguns "A Shooting Gallery Called America", undated, unpaginated pamphlet.

${ }^{134}$ Malcolm, GUNS AND VIOLENCE, ch. 6. We should clarify that the twin trends toward more violent crime and more gun control began long before the 1990s, and just culminated then. See Greenwood as quoted in the text accompanying fn. 33 supra.

135 "Britain Plans Criminal Justice Changes to Favor the Victims," NEW YORK TIMES, July 18, 2002, Section A; Page 8.

136 “Gun fears spur U.K. review," REUTERS/VARIETY dispatch, London, Jan. 15, 2003. This can occur in England because, once again, it has no written constitution to protect free expression. 
investigate burglary and "minor assaults". ${ }^{137}$ As of 2006, if the police stumble across a mugger, other robber or burglar, or other "minor" criminal, the policy is to release them with a warning rather than to arrest and prosecute them ${ }^{138}$. It used to be that English police vehemently opposed the idea of armed policing. Today ever more police are being armed. Justifying the assignment of armed squads to block roads and carry out random car searches, a police commander asserts: "It is a massive deterrent to gunmen if they think that there are going to be armed police. ${ }^{.139}$ How far is that from the rationale on which 40 American states have enacted laws giving qualified, trained citizens the right to carry concealed guns? Indeed, news media editorials have appeared in England arguing that civilians should be allowed guns for defense and the government recently decided to reconsider the 1997 handgun ban. ${ }^{140}$

137 “Gun-free UK: Don't bother about burglary, police told.” LONDON TELEGRAPH, December 1, 2003: "Police have been ordered not to bother investigating crimes such as burglary, vandalism and assaults unless evidence pointing to the culprits is easily available, The Telegraph can reveal. Under new guidelines, officers have been informed that only "serious" crimes, such as murder, rape or so-called hate crimes, should be investigated as a matter of course. In all other cases, unless there is immediate and compelling evidence, such as fingerprints or DNA material, the crime will be listed for no further action." http://news .telegraph.co. uk/news/-

main.jhtml?xml=/news/2003/01/12/nburg12.xml\&sSheet=/news/2003/01/12/ixnewstop.html/news/2003/01/12/nburg 12.xml:

138 “"Let burglars off with caution' police told."

http://www.dailymail.co.uk/pages/live/articles/news/news.html?in_article_id=381799\&in_page_id=1770

${ }^{139}$ See, e.g. REUERS dispatch, London, Sept 7, 2002: "British police will set up armed checkpoints on the streets of London to crack down on drug-related gun crime."

${ }^{140}$ Column by LONDON DAILY MAIL columnist Simon Heffer: "If the state fails us, we must defend ourselves." LONDON TELEGRAPH, February 2, 2002; "Dunblane handgun ban under review,"

Aug.11, 2002, /www.scotlandonsunday.com/index.cfm?id=874132002. 


\section{Quasi-experiments: Do Restrictive Gun Laws Reduce Violent Crime?}

This section examines the claim that restrictive gun laws are effective in bringing down violent crime. The logic is straight forward. If the approach to violent crime generally adopted by countries in the British Commonwealth is more effective than that adopted by the U.S., then, other factors being equal, the crime rates in those countries should fall faster than the corresponding crime rate in the US. On the other hand, if restrictive gun laws are not as effective in reducing violent crime, there may be no difference in the trends, or the crime rates in the U.S. may even fall faster. The uniqueness of the criminal justice system in the United States makes the US a singularly valuable point of reference. ${ }^{141}$ To recap our earlier discussion in the INTRODUCTION: not only are criminal penalties typically more severe in the United States, often much more severe, even including capital punishment, but also conviction and incarceration rates are usually much higher than they are in the British Commonwealth. ${ }^{142}$ Perhaps the most striking difference is that the United States is one of the few countries to encourage qualified citizens to carry concealed handguns for self defence.

Two sets of countries in the British Commonwealth are examined in this section. First, we will look at three countries that introduced laws restricting general access to firearms in the

\footnotetext{
${ }^{141}$ For a more thorough discussion of the differences among a wide variety of countries, including the United States, see David Kopel, THE SAMURAI, THE MOUNTIE, AND THE COWBOY, Prometheus Books, 1992

${ }^{142}$ These points have been made most tellingly by Patrick Langan and David Farrington (1998), CRIME AND JUSTICE IN THE UNITED STATES AND IN ENGLAND AND WALES, 1981-96. NJC 169294 (October). Washington, DC: Bureau of Justice Statistics, US Department of Justice, who compare the criminal justice systems of the United States with that of England and Wales. See also Marie Gannon, "Crime Comparisons between Canada and the United States." JURISTAT 21, 11 (December, 2001) for a thorough discussion of the differences in measurement of crime rates in the United States and Canada.
} 
1990s. Next, we will compare the crime trends in two countries that attempted near comprehensive firearms bans in the 1970s. In each of these countries, we shall compare the trends in violent crime, including homicide trends, with the general decline in violent crimes in the United States over the same time period.

It is important to remember that the goal clamed for these firearm laws is to create a safer society by reducing total criminal violence, not just gun violence. As we have argued earlier in this paper in ASKING THE WRONG QUESTION, the determinants of murder and suicide are basic social, economic and cultural factors not the prevalence of any particular deadly mechanism. Thus it follows that to evaluate the effectiveness of firearms legislation, one must measure the increase or decrease in criminal violence as a whole. The question that needs to be addressed is not whether gun laws cause a drop_-or an increase-in firearms crime. If gun crime declines but crimes with other weapons just increase so that the number of violent crimes does not decline gun control fails. ${ }^{143}$

The crucial question is whether or not the gun laws improve public safety. There is no social benefit in decreasing the availability of guns if the result is only the increase of other means of committing suicide and murder with no decrease in the number of lives lost. Note that even if firearm regulations were successful in causing firearms crime to drop, other violent crimes could increase to such an extent that society might actually be less safe. The evidence, as we will show, indicates that all that is accomplished by the removal of one particular means from people who are motivated to suicide or murder by social, economic, cultural or other circumstances is their

\footnotetext{
${ }^{143}$ There is little evidence that gun laws are effective in reducing homicide or violent crime. See for example, Joyce Malcolm, GUNS AND VIOLENCE: THE ENGLISH EXPERIENCE. Cambridge, MA: Harvard University Press, (2002).
} 
killing themselves or others by some other means.

In assessing the impact of legislation on crime rates, it is necessary to examine changes over time. Obviously, directly comparing national averages is irrelevant. It is an entirely different question whether the Canadian average for a particular crime rate is higher (or lower) than that of the United States or England. Such patterns speak to the historical and cultural differences among nations, not to the effectiveness of recent firearm legislation ${ }^{144}$. Evaluating legislation is analogous to evaluating a new diet. If we want to determine if our new diet is effective, we must ask if our weight changes after the diet is introduced. While it may be reassuring, it is logically irrelevant to our diet's efficacy that other people are fatter than we are.

Of course, even if crime rates decline after the introduction of a new firearm law, this does not prove that the legislation caused the decline. There may be alternative explanations for the change that are more persuasive. The question of causality is never fully answered even in complex econometric analyses or in experiments conducted under strict laboratory conditions. All that anyone can do is to attempt to eliminate most of the alternative explanations. By examining the trends in crime rates in several diverse countries, we conclude that the alternative factors can be discounted. The fact is that in none of these cases, despite the variety of countries examined, do violent crime rates drop as a consequence of the introduction of more restrictive firearm laws. Comparative studies rely upon police statistics. There are several reasons for this decision

\footnotetext{
${ }^{144}$ Arguably, one of the reasons that violent crime rates tend to be higher historically in the United States and Jamaica than in Canada is that slavery played a smaller role in Canada than in either Jamaica or the United States. Slavery had been abolished in Canada by 1810 by Lieutenant Governor John Graves Simcoe. For more information about slavery in Canada, see Michael Craton, SINEWS OF EMPIRE: A SHORT HISTORY OF BRITISH SLAVERY, Anchor Books, Garden City, NY, 1974.
} 
even though there are well-known limitations to police data ${ }^{145}$. The first is that police statistics are the only data that are consistently available for the range of countries that we are considering over the full thirty years. Second, not only are victim surveys often unavailable for some countries, ${ }^{146}$ but also the most important index of criminal violence is homicide, as to which victim surveys are not possible. Third, despite their high reputation, victim interviews are of strikingly uneven quality both across nations and within nations across time. Last, police statistics are published annually while victim surveys are only conducted irregularly, at most every five years.

The first countries we shall compare are Australia, Canada and the United Kingdom. Each of these countries introduced Draconian general laws in the 1990s that severely restricted access to firearms by citizens in an effort to improve public safety. Not only do these countries share the common history of the British Commonwealth, they are large western democracies with a modern, functioning police force, customs bureaucracy, and a highly educated population. If any countries could be expected to be able to control firearm misuse through the legal system, these countries should qualify.

\section{The United Kingdom ${ }^{147}$}

Firearm policy in the United Kingdom has been driven by sensationalized coverage of

\footnotetext{
${ }^{145}$ Police statistics have been criticized because they are subject to changes in the public's willingness to report crimes, and, equally important, to variations in police recording practices.

${ }^{146}$ Excellent victim surveys exist in Australia, Canada, the United States, as well as in England and Wales, but not in Scotland, Northern Ireland, the Republic of Ireland, or Jamaica. See Sian Nicholas, David Povey, Alison Walker and Chris Kershaw, CRIME IN ENGLAND AND WALES 2004/2005. Home Office Statistical Bulletin, National Statistics, London, England, July 2005.

${ }^{147}$ The United Kingdom consists primarily of three large jurisdictions, England and Wales, governed for the most part as a single entity, Scotland, and Northern Ireland. The crime trends of the Channel Islands and other nearby islands associated with the U.K. will not be examined here.
} 
firearm murders for over 15 years. First, in August 1987, a deranged man stalked through the small town of Hungerford, England for eight hours shooting people seemingly at whim. By the time the killing was over, Michael Ryan had killed 16 people and wounded another 14, before shooting himself ${ }^{148}$. Media attention focused almost exclusively on how Ryan had managed to obtain firearms legally. In hindsight other matters seem of at least equal interest. For instance the fact that English police are disarmed meant they could not stop him. In contrast, such massacres have been prevented or stopped in the U.S. and Israel where citizens have guns ${ }^{149}$.

Almost 10 years later, in 1996, in Dunblane, Scotland, Thomas Hamilton, who was known to the police as mentally unstable, walked into a primary school with his legally registered handguns and murdered 16 young children and their teacher. Before killing himself, he wounded another 10 students and three teachers. ${ }^{150}$ The media were outraged that licensed target shooters were able to own handguns, not that the police failed to follow the rules that should have prevented granting the killer a firearm permit. According to information presented to the Cullen Commission, Hamilton had been refused membership in several gun clubs, which had requested the police to revoke his permit. The police had not acted on these complaints ${ }^{151}$. 201.

${ }^{148}$ Joyce Lee Malcolm. GUNS AND VIOLENCE: THE ENGLISH EXPERIENCE, Harvard Press, 2002, p

${ }^{149}$ See Lott, BIAS AGAINST GUNS, ch. 6. In one case, the school principal stopped a shooting in his school by retrieving his lawfully owned handgun, "A principal and his gun," Wayne Laugesen, BOULDER WEEKLY, http://www.BoulderWeekly.com. Other examples are available on http://www.keepandbeararms.com/. "Armed Israeli civilian stops terrorist attack," FOX NEWS CHANNEL, 4 November 2001. A large percentage of the Israeli population has permits for carrying concealed handguns. Abraham Rabinovich, "Israel OKs 60,000 more gun permits in terror fight," WASHINGTON TIMES, 7 March 2002 and "Army issuing 40,000 handgun permits," IsraelNN.com, 6 March 2002.

${ }^{150}$ Malcolm, op cit, p 203.

${ }^{151}$ See THE CULLEN COMMISSION, TRIBUNALS OF INQUIRY. INCIDENT AT DUNBLANE PRIMARY SCHOOL ON 13 MARCH 1996 BEFORE THE HON. LORD CULLEN, Glasgow, Scotland (1996). Available from http://www.open.gov.uk/. 
The Firearms (Amendment) Act of 1988 was brought in by the Conservative government following the Hungerford incident, and the Firearms (Amendment) Act of 1997, which banned all handguns, was introduced by the Labour government following the shooting in Dunblane in $1996^{152}$. Unfortunately, these Draconian firearm regulations have not curbed crime.

\section{England and Wales}

Assessing the impact of this legislation requires examining each of the principal jurisdictions of the UK in turn. England and Wales are administered as if they were a single jurisdiction; taken together, England and Wales comprise about $88 \%$ of the UK population.

Police statistics show that England and Wales are enduring a serious crime wave. In contrast to North America, where the homicide rate has been falling for over 20 years, the homicide rate in England and Wales has been growing over the same time period. (See Figure 1). In the 1990 s alone, the homicide rate jumped 50\%, going from 1.1 per 100,000 in 1990 to 1.6 per 100,000 in 2000 , and the homicide has remained higher, averaging 1.7 per 100,000 since $2001^{153}$

As for violent crime in general, police statistics show a huge increase since the handgun ban, and since 1996 violent crime has been more serious than in the United States (See Figure 2). 16 The rate of violent crime has jumped from 400 per 100,000 in 1988 to almost 1,400 per 100,000

\footnotetext{
${ }^{152}$ Colin Greenwood, Colin, "Labour's Gun Plan." SHOOTING TIMES AND COUNTRY MAGAZINE April 12, p 8, 2001; R.A.I. Munday and J.A. Stevenson. GUNS AND VIOLENCE: THE DEBATE BEFORE LORD CULLEN. (Essex, Eng., Piedmont: 1996).

${ }^{153}$ Home Office (2001). CRIMINAL STATISTICS, ENGLAND AND WALES, 2000. Norich, England: Queen's Printer; JURISTAT: Canadian Centre for Justice Statistics pamphlet "Homicide in Canada, 2001" by Mia Dauvergne at p 3; "Homicide in Canada, 2002" by Josee Savoie at p 3; "Homicide in Canada, 2003" by Mia
} 
in 2000. (An unknown amount of the recent increase may be attributed to changes in the recording rules in 1998 and 1999.) In contrast, not only are violent crime rates lower in the United States, there they are continuing to decline ${ }^{154}$.

The Home Office has also tightened up on enforcement of regulations to such an extent that the legitimate sport-shooting community has been virtually destroyed. For example, shotgun permits have fallen almost $30 \%$ since $1988^{155}$ (See Figure 3). The British Home Office admits that only one firearm in 10 used in homicide was legally held ${ }^{156}$ (See Figure 4). But, there is little pressure from within bureaucratic and governmental circles to discontinue the policy of disarming responsible citizens who hold their firearms for target shooting or for taking game for the table, after some centuries of being allowed to do so by the law.

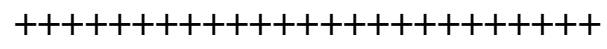

Figures 1 - 4. England and Wales

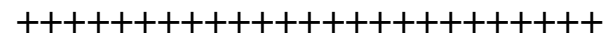

Clearly, there is no evidence that firearm laws have caused violent crime to fall. The firearm laws may even have increased criminal violence by disarming the general public. Despite banning and confiscating all handguns, violent crime — and firearm crime-continue to grow. The

Dauvergne at p 3 (Table titled Homicide Rates for Selected Countries, 2002); and "Homicide in Canada, 2004" by Mia Dauvergne at p 3 (Table titled Homicide Rates for Selected Countries, 2004).

${ }^{154}$ Home Office 2001, op cit.; Federal Bureau of Investigation (2003). UNIFORM CRIME REPORTS, TABLE 1: INDEX OF CRIME, UNITED STATES, 1982-2001. Digital document available at http://www.fbi.gov/ucr/01cius.html.

${ }^{155}$ Greenwood, op cit,

${ }^{156}$ Home, Office, op cit, 2001, p 
number of violent crimes involving handguns has increased from 2,600 in 1997/1998 to 3,600 in 1999/2000. Firearm crime has increased $200 \%$ in the past decade. At the same time, violent crime and homicide continue to fall in the United States.

\section{Scotland}

Scotland has almost $9 \%$ of the total population of the United Kingdom. Firearms laws are essentially the same in Scotland as in England, despite differences between the English and Scottish legal systems. Historically, Scotland has its own police and judiciary. Scottish semiindependence was further recognized with devolution in 1998 and the creation of a Scottish Parliament with very limited powers ${ }^{157}$. Any criminal legislation that is intended to apply to Scotland as well as to England and Wales has to be achieved by adding a distinct appendix to legislation, or by passing a separate Act for Scotland. Nevertheless, the criminal law in Scotland is nearly identical to that in England and Wales.

As can be seen in Figure 5, the crime trend in Scotland resembles that in England and Wales. The restrictive firearms laws have failed to slow down murderers; homicides continue to increase. Prior to 1997, there were 104 homicides per year for the previous ten years. 1997 was an exceptionally low year, with only 90 homicides, but homicides have continued to increase. Since the handgun ban, there have been 110 homicides each year through 2003, but for the past three years (2001-2003) there have been 114 homicides per year. ${ }^{158}$

\footnotetext{
${ }^{157}$ Gillian Peele. GOVERNING THE UK, THIRD EDITION, Blackwell, Oxford, UK, p. 417; Phil Cocker and Alistair Jones, op. cit, 2002, pp. 252-254

${ }^{158}$ Scottish Executive, HOMICIDE IN SCOTLAND, 2003 - STATISTICS PUBLISHED. Justice Department, Criminal Justice Division, 24 November 2004. Note that the increase in the frequency of homicide
} 
Violent crime in general is also increasing. This is evident in both police statistics and victim surveys. Violent crime has increased from 14,500 in 1994 to over 15,000 in 2001, 2002 and 2003. Over the same time period, rape and attempted rape has also increased from under 6,000 per year to over 6,500 per year ${ }^{159}$. A recent victim survey, conducted as part of a United Nations sponsored survey of crime victims in 21 countries, identified Scotland as one of the most violent places in Europe ${ }^{160}$.

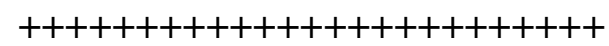

Figure 5. Homicide Trend in Scotland

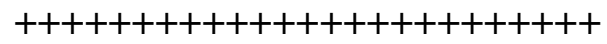

\section{Northern Ireland}

Northern Ireland constitutes the third and smallest political unit of the United Kingdom to be analyzed here. Northern Ireland was created in 1921, at the same time as the Irish Free State (now the Republic of Ireland or Eire) gained its independence ${ }^{161}$. It has less than $3 \%$ of the total population of the United Kingdom, but its population is growing rapidly. Although Northern

represents a real growth in the Scottish homicide rate because the population of Scotland decreased by approximately $1 \%$ between 1992 and 2003.

${ }^{159}$ Scottish Executive, RECORDED CRIME IN SCOTLAND, 2003. Criminal Justice Series, CrJ2004/5, June 2004.

${ }^{160}$ Katrina Tweedie. "Scotland tops list of world's most violent countries," THE TIMES, London, September, 19. 2005. http://www.timesonline.co.uk/article/0,2-1786945,00.html

${ }^{161}$ In 1949, the Irish Free State changed its name to Eire or the Republic of Ireland. 
Ireland has had its own parliament in Stormont from the onset, this was suspended in 1972 when the British government instituted Direct Rule as a result of the tremendous growth in sectarian violence $^{162}$. British troops had been sent into Northern Ireland in 1969 in order to separate the warring paramilitary forces and to re-establish order. Under Direct Rule, Northern Ireland was governed from London by a Secretary of State.

Since 1994, there have been great strides towards peace, and accordingly, Northern Ireland has once more been granted increasing powers of self-rule. Elections to the Northern Ireland Assembly were re-introduced in 1998. Northern Ireland has substantially the same criminal code as the rest of the United Kingdom, but the sectarian violence since 1969 has led to a number of important differences. These include generally much more restrictive firearms laws, but with one important, possibly crucial, difference.

As a matter of Home Office policy, Firearm Certificates ceased to be issued anywhere in the UK for self-defence in the 1950s. Uniquely in Northern Ireland, police officers were routinely allowed to carry personal protection firearms until this exception was ended in 1969 as a result of the Hunt Report. The original policy was reinstated about 10 years later, with little or no publicity, as a result of the dramatic increase in the number of disarmed police officers who had been murdered ${ }^{163}$.

Concurrently, Home Office policy during the 1980s allowed the issuance of Firearm

\footnotetext{
${ }^{162}$ Phil Cocker and Alistair Jones, op. cit, 2002, pp. 262 -

${ }^{163}$ Sutton, M. 1994. AN INDEX OF DEATHS FROM THE CONFLICT IN IRELAND, 1969 - 1993.

Belfast, Beyond the Pale Publications, cited in Brewer, et al., 1997.

The Patten Report on policing in Northern Ireland notes:

"... (W)e were reminded on several occasions that, when the RUC had been disarmed after the Hunt report of 1969 , there was a spate of attacks on police resulting in the deaths of several officers and leading to the re-introduction of personal protection weapons."
} 
Certificates, specifically for personal protection, to a range of officials perceived to be especially at risk: for example, politicians and retired and off-duty police, prison warders and military personnel. It is possible that this policy contributed to the substantial reduction in the murder rate that followed, although this has yet to be evaluated.

In response to a question in the UK Parliament in 1998 about extending the imminent pistol ban to Northern Ireland, the government stated that there were some 10,000 personal protection Firearm Certificates in issue, compared with 2,000 issued for sporting purposes. It is widely understood that the UK government wished to extend the ban to Northern Ireland and were only persuaded not to when several politicians in Northern Ireland made it very clear that, if their Certificates for personal protection firearms were withdrawn, they would cease to support the so-called "Good Friday Agreement" of 1998, which the UK government regarded as a vital part of the peace process. The UK government therefore reluctantly agreed to Northern Ireland being excluded from the pistol ban.

As may be seen in Figure 6, Northern Ireland is the only segment of the UK where the murder rate is declining. It is also interesting to note that many other crime rates are lower in Northern Ireland than in the rest of the UK. The reasons for these differences are not readily apparent. The policy of issuing Firearm Certificates for personal protection is probably not a significant factor, as they are only issued to a very small proportion of the population ${ }^{164}$. The emergency police powers, including the Draconian police presence, are probably a much more important factor. Another and equally persuasive hypothesis, given that the vast bulk of the

\footnotetext{
${ }^{164}$ Arguably, since a criminal's fear of being shot is stronger than his fear of being caught by police, the presence of even a small percentage of armed citizens is sufficient to dissuade some criminals. Although this is more
} 
murders in Northern Ireland are political, is that government negotiations with the paramilitary forces played an important role in causing homicide to fall.

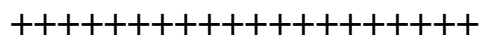

Figure 6. Murder Trend in Northern Ireland

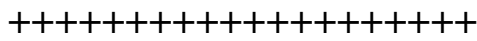

\section{Australia}

Publicity surrounding a multiple murder triggered recent changes in Australian firearm policy. In Port Arthur, Tasmania, on April 28, 1996, Martin Bryant, a mentally deranged man, went on a rampage murdering anyone he encountered. The media afterwards focused almost exclusively on the killer's use of military-style semi-automatic firearms. The police arrived, surrounded the isolated building, and began negotiations. When he tried to escape, he was quickly captured $^{165}$. In all, he killed 35 people and seriously injured another 18 . He was tried and sentenced to life in prison ${ }^{166}$. Confusion remains over many of the details of this incident, including how Bryant came to have the firearms he used, and whether or not the police response was adequate. No Royal Commission has ever examined the incident. The media focus on the type of firearms used at Port Arthur has diverted public concern over police procedures.

Following garish media coverage of the Tasmanian killings, in 1997 the Australian government brought in sweeping changes to the firearm legislation. The new controls on firearms

likely to be an effective remedy in the United States where there is a significant fraction of armed citizens. This is much less likely in Northern Ireland where so few people carry concealed weapons for protection.

${ }^{165}$ See Bellamy, Patrick (2003). MARTIN BRYANT. Digital document available at http://www.crimelibrary.com/serial/bryant. 
introduced included the prohibition and confiscation of over 600,000 firearms, mostly semiautomatic or pump-action firearms, from their licensed owners, as well as new licensing and registration regulations ${ }^{167}$.

Unfortunately, these new firearm regulations do not appear to have made the streets of Australia safer. Consider homicide rates. Homicide involving firearms has declined but murders with other weapons just increased so the total homicide rates have remained basically flat from 1995 through to $2001^{168}$. In a subsequent report, Dr. Mouzos reports that, despite the declining firearm homicides, there is an increase in multiple-victim incidents. However, reports show that homicide rates have declined in both 2003 and $2004^{169}$. It is not clear what is driving these recent declines. Nevertheless, homicide rates remain at a historic high. Shortly after World War II, the Australian homicide rate was around 1 per 100,000. Since then, it has climbed until it peaked at 2.4 per 100,000 in 1988 and another high of 2.0 in $1999^{170}$.

The decline in homicide rate in the United States stands out against the essentially stable homiode rate in Australia (See Figure 7). In the US, the homicide rate has dropped 32\% between 1995 and 2001, while it has slid only 10\% in Australia. At the same time Australia banned and

\footnotetext{
${ }^{166}$ See Guirguis, Peter (2003). CRIME ANALYSIS: PORT ARTHUR MASSACRE. Digital document available at www.boredofstudies.cjb.net

${ }^{167}$ For further information on the firearms legislation, see Lawson, James B. (1999). "New National Gun Laws-Are They Cost Effective?" INSTITUTE OF PUBLIC AFFAIRS REVIEW 51, 4 (December): 27-28, and Peter Reuter and Jenny Mouzos (2002). "Australia: A Massive Buyback of Low-Risk Guns." Paper presented to the American Society of Criminology, Chicago.

${ }^{168}$ Mouzos, Jenny (2001). HOMICIDE IN AUSTRALIA, 1999-2000. Trends and Issues 187 (February). Canberra, ACT: Australian Institute of Criminology.

${ }^{169}$ Mouzos, Jenny (2003). HOMICIDE IN AUSTRALIA 2001-2002. Research and Public Policy Issues 46. Canberra, ACT: Australian Institute of Criminology.

${ }^{170}$ Graycar, A. (2001). "Crime in Twentieth Century Australia.” In YEAR BOOK AUSTRALIA, 2001, (ABS cat. no. 1301.0; Australian Bureau of Statistics, 2001): 477-95. Digital document available at http://www.aic.gov.au/publications/other/centenary/.
} 
confiscated legally owned firearms, the number of states in the U.S. that allow their residents to carry concealed handguns increased from 28 to 40 out of the total of 50 states.

$+++++++++++++++++$

Figures $7 \& 8$ Australian Trends

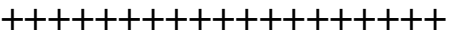

The divergence between Australia and the United States is even more apparent when one considers violent crime (See Figure 8). While violent crime is decreasing in the United States, it continued to increase in Australia for four years following 1997, although it has recently started to decline. In 2003, the violent crime rate had decreased by $22 \%$ in the U.S. since 1997, while it had increased by over $14 \%$ in Australia ${ }^{171}$. Assault rates have jumped from 623 per 100,000 in 1996 to 815 per 100,000 in 2002 , and easing just slightly to 798 per 100,000 in 2003 . Robbery jumped from under 90 per 100,000 prior to 1997 up to 137 per 100,000 in 1991 before returning to pre1997 levels in 2004. Despite the recent decline in violent crime in Australia, it is illogical to credit the 1997 firearm law for this drop given that violent crime did not decline for four years following the gun law.

The destruction of the confiscated firearms cost Australian taxpayers an estimated \$AUS500 million and has had no visible impact on violent crime ${ }^{172}$. The costs of the confiscation

\footnotetext{
${ }^{171}$ Violent crime is defined differently in the two countries, so they cannot be compared directly. The primary differences lie in how assault and particularly sexual assault are defined. In addition, in 2004, Australia withheld reporting on crimes of assault due to a concern over the definitional variance across reporting states.

${ }^{172}$ Lawson, 1999, op cit.
} 
do not include the costs of bureaucracy, which, as has been shown in Canada, can be considerable. Most likely in a bid to deflect possible criticism, the governments have made it difficult for the public to assess the full cost of this program. Robbery and armed robbery rates continued to rise after 1997. Armed robbery has increased $166 \%$ nationwide-jumping from 30 per 100,000 in 1996 to 50 per 100,000 in $1999^{173}$. The homicide rate has remained remarkably stable, while the share of firearm homicide involving handguns - which have also come under heavily increased restrictions - has doubled in the past five years ${ }^{174}$. The proposed solution to the failure of the 1997 gun regulations is to pass even more restrictions on handguns. This is all the more remarkable because in Australia, as in Great Britain and Canada, few firearms used in homicide are legally held; in 1999/2000 only 12 out of 65 (18\%) were identified as being misused by their legal owner ${ }^{175}$.

\section{Canada}

As in other countries, recent changes in firearm policy were precipitated by a media frenzy over a multiple murder. On December 6, 1989, Marc Lepine, born Gamil Gharbi, went to the University of Montreal campus, where he wandered around the halls of the engineering building shooting people he encountered while shouting hatred for feminists. In one classroom, after sending the men from the room, Gharbi shot the remaining women. In all, he killed 14 women

\footnotetext{
${ }^{173}$ Australian Institute of Criminology (2001). AUSTRALIAN CRIME, FACTS AND FIGURES, 2000. Canberra, ACT: Australian Institute of Criminology.

Mouzos, Jenny, and C. Carcach (2001). WEAPON INVOLVEMENT IN ARMED ROBBERY. Research and Public Policy Issues 38. Canberra, ACT: Australian Institute of Criminology.

${ }^{174}$ Mouzos, 2001, op cit.

${ }^{175}$ Mouzos, 2001, op cit.
} 
and wounded another 13 students, including four men, before he finally shot himself (Jones 1998). Even though Gharbi encountered almost one hundred students and at least three teachers, no one tried to stop the murderer. It is very difficult for unarmed civilians to resist an armed criminal.

An investigation by the Montreal coroner severely criticized the police for their inadequate response ${ }^{176}$. The police did not even arrive until after the killings were over. After taking 30 minutes to arrive at the university campus, the police could not find the engineering building. The coroner's office stated that the type of weapon used was not a significant factor in the murders. Nevertheless, political activists used this hideous crime to launch a campaign that promoted tighter firearm restrictions as the way to protect women from male violence. The obvious misogyny of the crime energized Canadian feminists to become politically active. As a result, Canada twice introduced sweeping changes to its firearms laws, first, in 1991, under the Conservative government and then again, in 1995, under the Liberals, before the first changes had been fully implemented. These changes included prohibiting over half of all registered handguns in 1995, and requiring the registration of long arms (i.e., rifles and shotguns) in $1998^{177}$.

The Canadian homicide rate has remained essentially stable since the mid-1990s after declining during the early 1990s. in 2004 it began to increase again. Over this same time period, firearm murders have also declined, although this has been partially compensated by increases in murders involving knives and clubs. While the Canadian homicide rate has stabilized, in the

\footnotetext{
${ }^{176}$ MacDonald, Don (1990). "Killer Lepine Had 60 Shells Left: Report on Montreal Massacre." EDMONTON JOURNAL (May 15): A1.
} 
United States the homicide rate has plummeted (see Figure 9). Between 1991 and 1997, the homicide rates in both Canada and the U.S. fell by $32 \%$. Since 1997, the homicide rate in the United States has fallen an additional 19\%, from 6.8 per 100,000 in 1991 to 5.5 per 100,000 in 2004, while the Canadian rate has remained stable at 1.8 - 1.9 per 100,000.

The contrast between the rate of criminal violence in the United States and that in Canada is much more dramatic (see Figure 10). Over the past decade, the Canadian violent crime rate has stayed basically stable while, in the United States during the same time period, the rate of violent crime has slid from 600 per 100,000 to 500 per $100,000^{178}$.

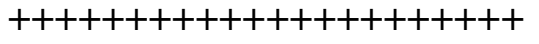

Figures $9 \&$ 10. Canadian Trends

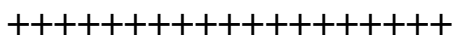

The Canadian experiment with firearm regulation is moving towards farce. Although it was originally claimed that this experiment would cost only $\$ 2$ million $(\$ C)$, the Auditor General reported in 2001 that the costs of the firearm registry were out of control and would be more than $\$ 1$ billion (\$C). Unfortunately, her mandate was limited so she could not examine the entire sprawling program. The final costs are unknown but, if the costs of enforcement are included, estimates now reach $\$ 3$ billion ( $\$ \mathrm{C})$. It is important to recognize that the costs of any proposed scheme to regulate firearms are significant, and that these costs are not easy to estimate in

\footnotetext{
${ }^{177}$ Handguns have been required to be registered in Canada since 1934. See the Canadian Firearms Centre for a description and history of Canadian firearm legislation. http://www.cfc-cafc.gc.ca/pol-leg/hist/firearms/default_e.asp

${ }^{178}$ Gannon, Maire (2001). “Crime Comparisons between Canada and the United States.” JURISTAT 21, 11
} 
advance, even in a modern, economically developed country such as Canada. More important, the introduction of any expensive program, such as universal firearm registration, means that reductions must be imposed on expenditures on other policing priorities because of limited budgets. In Canada, the police budget was basically frozen the 1990s, that is, after inflation is factored in, there has been no real increase in the budget.

Though the primary purpose of firearms registration is to disarm legally unqualified persons the Ministry has discontinued background investigations in order to speed up the protracted process. For an unknown period, people presenting a gun for registration have been allowed to register it to them apparently on the presumption that they have no criminal background to legally disqualify them from owning firearms. ${ }^{179}$ This has resulted in the RCMP announcing that it does not trust the information in the registry ${ }^{180}$.

Another problem is that a computer glitch has prevented or wiped out an unknown number of registrations. An estimated million or more Canadians have failed to register, ${ }^{181}$ and critics claim the glitch precludes prosecuting them since now scoflaws cannot be distinguished from registrants whose registrations were lost in the glitch. The Minister replied that the deadline will not once again be extended to allow further or re-registrations and any gun owner not recorded as having registered would be prosecuted, regardless of the inaccuracies and lacunae in the

(December).

${ }^{179}$ Mauser papers, supra. The $\$ 2$ billion estimate comes from Prof. Mauser. See also: Garry Breitkreuz, MP. "CFC Statistics: Firearm Licence Refusals \& Revocations, by Reason, by Province as of February 1, 2004 http://www.garrybreitkreuz.com/publications/RefusalsandRevocationsbyReas on2004-02-01.xls

${ }^{180}$ REPORT OF THE AUDITOR GENERAL OF CANADA, Chapter 11, "Royal Canadian Mounted Police - Canadian Firearms Program”.

http://www.oag-bvg.gc.ca/domino/reports.nsf/html/20021211ce.html\#ch11hd3c 
registry. $^{182}$

An even more serious problem is that the security of the firearm registry has come under question due to a series of large-scale robberies from gun collectors and gun shops in southern Ontario. These robberies appear to have been specifically targeted by criminals who had access to inside information about the locations of gun collections. According to a former employee of the Canadian Firearms Centre, anyone with a home computer, an Internet connection and a little patience can hack into the national firearms database and find out who owns guns, where they live and what makes and models they possess. ${ }^{183}$

The countries considered to this point (Australia, Canada, United Kingdom) merely attempted to restrict certain types of firearms or to register firearms. The reader may perhaps ask whether a more thorough firearms ban would have been more effective. The next two countries to be discussed did in fact attempt to ban the ownership of virtually all firearms.

In the 1970s, both the Republic of Ireland and Jamaica prohibited virtually all citizens from owning firearms. These countries did not simply regulate firearms, or ban a particular type of dangerous firearm, but instead they attempted a comprehensive ban of nearly all firearms. Each of these countries did so in a desperate effort to break the spiral of violence that had infected it.

\footnotetext{
${ }^{181}$ Mauser, MISFIRE, supra; Jacobs, CAN GUN CONTROL WORK 149, second footnote.

${ }^{182}$ See generally Tim Naumetz, "Glitch wipes out firearms records; No amnesty, minister insists; charges impossible, Alliance MP replies," THE OTTAWA CITIZEN, June 05, 2003 and Canada News Briefs, "Names deleted from firearms registry," ASSOCIATED PRESS June 4, 2003. There is apparently no question that some registrations have been lost, but it is unclear and disputed how many were lost and whether the cause was a computer "crash" or some different malfunction.
} 


\section{The Republic of Ireland ${ }^{184}$}

Concerned with the rapid rise of sectarian violence in Northern Ireland, on $2^{\text {nd }}$

\section{August 1972 the Irish Republic issued a Firearms Temporary Custody Order under the}

extraordinary powers it had given itself in the 1964 Firearms Act, Clause 4. It required no debate

in Parliament; it became Law as soon as the Minister for Justice issued the Order. ${ }^{185}$ Virtually all

firearms were required to be surrendered to the authorities within three days.

Even though the Irish Republic was not hit as hard as its northern neighbor, the threat was

perceived as very real and the Irish Government claimed that the risk of the IRA stealing firearms

from private homes justified the Custody $\operatorname{Order}^{186}$. Nevertheless, the number of murders in the

Republic of Ireland doubled with the introduction of the Custody Order, from an average of under

13 murders per year in the years up to and including 1971, to 28 murders in 1972. It remained at

the new higher average level for the next 20 years, when it started to rise again to its present level

of about 45 murders per year. ${ }^{187}$ Even more troubling, the murder of police officers rose

${ }^{183}$ Mark Bonokoski, TORONTO SUN, "In the wake of firearms thefts, it's possible the gun registry is not as secure as touted," March 10, 2006, p10. Janice Tibbits, MONTREAL GAZETTE, "Gun registry called a breeze to hack by ex-webmaster," March 13, 2006, p A10.

${ }^{184}$ The Republic of Ireland shares a relatively small island with Northern Ireland. The Republic is a separate country that won its independence from Britain in 1921 after a long and bloody struggle. Northern Ireland, also called Ulster, is part of the United Kingdom, along with England, Wales and Scotland. There is a substantial tension between the Protestant and Catholic communities in Northern Ireland where there has been a history of long and bitter sectarian violence.

${ }^{185}$ This legislation included all handguns, including air guns, and all rifles over .22 caliber. Thus shotguns and .22 rifles were excluded.

186 The recent 30-year period of violence, colloquially called "The Troubles', began with Civil Rights marches in 1968, but rapidly escalated into extreme violence. Murder in Northern Ireland jumped from 5 per year up to 1968 , to 123 in 1971 , and then to 376 in 1972.

${ }^{187}$ Murder statistics for the Republic of Ireland are given as raw frequencies rather than rates per 100,000 population. In this way we can avoid any possible error introduced from over (or under) estimating annual population increases. The Republic of Ireland has grown but slowly over the past thirty years; the population has only increased by $3 \%$ over the past 15 years. 
dramatically as well. When Officer Fallon was murdered in 1970, with an illegal pistol, it was the first murder of a police officer for 28 years; but in the 29 years that followed, another 13 officers were murdered, all with illegally-held firearms. With a substantially static population, these figures represent dramatic rate increases. Apart from allowing small caliber hunting rifles (calibers up to .270) in 1993, the Firearm Custody Order continued to be enforced right up until the summer of $2004^{188}$.

Clearly, the evidence linking the doubling of the murder rate to the introduction of the Custody Order is only circumstantial. Nevertheless it can clearly be seen from Figure 11 that government efforts, including the Draconian Firearms Custody Order and its extension for 32 years, certainly did not bring the murder rate down. This failure is repeated in many other countries.

Other violent crimes have also increased over the past thirty or so years. Figure 12 shows that the number of robberies jumped up from under 500 per year in the early 1970 s to over 2,000 per year in the early 1980s, and even hit 3,500 in 1995. There were about 3,000 robberies in 2002, the most recent year for which statistics are available.

In hindsight, it appears difficult to believe that banning and confiscating firearms from target shooters, hunters and farmers could ever have been imagined to be a successful strategy to combat an organized group of terrorists such as the IRA. Nevertheless the Irish government and police steadfastly pursued it for 32 years, regardless of its questionable legality, until forced to

\footnotetext{
${ }^{188}$ We are indebted to Mr. Derek Bernard for supplying the information about the murder of Officer Fallon and the detailed nature of the Irish firearms laws. Personal communication, Derek Bernard, October 27, 2005.
} 
abandon it by legal action $^{189}$.

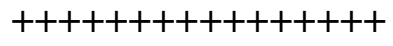

Figures $11 \& 12$. Violent crime trends in the Republic of Ireland

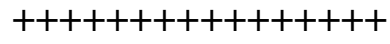

\section{Jamaica}

In the early 1970s, Jamaica was shocked by a horrifying increase in drug-related violence involving guns. The murder rate jumped from between 6 and 7 deaths per 100,000 population in the late 1960 s to 8 per 100,000 in 1970 and over 11 per 100,000 by 1973 . In response, the Jamaican government decided to introduce the Gun Court Act in 1974. The Gun Court was a drastic institution that eliminated many safeguards in the British legal tradition such as open hearings and trial by jury (although these were retained for capital cases only). The standard, mandatory sentence for almost any firearm offence, even the illegal possession of a single cartridge, was life imprisonment. Those charged would be imprisoned without bail until tried, often for 2 years or more.

In 1982 and 1983, these conditions were relaxed somewhat. They nevertheless remain draconian to the present day.

189 This legislation has recently been overturned in an Irish court. At the time of writing, the Custody Order and associated firearm ban has gone, only to be replaced by massive obstructionism and delay, defended usually on 


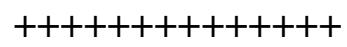

Figures $13 \&$ 14. Jamaica -- murder, shootings

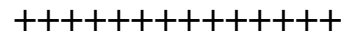

The results of the Jamaica Gun Court were not encouraging even though the number of murders dropped the year the Gun Court was introduced. In 1973, before the Gun Court, 227 people were murdered, and in 1974 , this number fell to 195 . Unfortunately, the number increased in 1975 to 266 people murdered, and it increased again to 367 people in 1976. Despite the continuation of draconian controls on firearms, the number of people murdered has continued to increase. In 2001, the most recent year statistics are available, there were 1,139 people murdered in Jamaica.

The raw figures do not tell the full story because of population changes. Consequently, we have calculated murder rates per 100,000 people in the general population. As may be seen in Figure 13, the murder rate jumped more than 50\% from 9 per 100,000 to over 16 per 100,000 from the early 1970 s to the mid-1970s and has continued to climb. The gun ban did not reduce on gang shootings, and violent crime rates continued to increase. See Figure 14. A few years after the introduction of the Gun Court, the murder rate reached a deplorable figure of over 40 deaths per 100,000 , but it soon fell back down to between 18 and 19 per 100,000 for the rest of the 1980s. The murder rate began climbing again in the 1990s until it surpassed even the previous high in 2001 with 43 murders per 100,000.

It is difficult to argue that the Gun Court was successful. Perhaps more so than most, 
Jamaica is a special case. The two major political parties are rumored to have both consistently employed criminal gangs to terrorize their opponents; and, as a result of political corruption, these gangs have no trouble in smuggling whatever offensive weapons they desire. In a very real sense the gangs associated with whichever party happened to be in power were above the law. In addition, about a third of the killings are claimed to be committed by the police, the vast majority in suspicious circumstances, according to Americas Watch, a human-rights group ${ }^{190}$. Let us remember that people accused of nothing more than the ownership of a single bullet lost their most basic legal rights and were punished with sentences harsher than those served for murder in other societies. As would be expected, there is no shortage of hypotheses about who or what is to blame. Each political party blames the other, and both blame the United States. In all the finger pointing, it is clear that the crackdown on firearms did not manage to reduce either gun crime or criminal violence.

In summary, no evidence can be found for arguing that firearm prohibitions were effective in reducing murder, firearm murder, or violent crime in either the Republic of Ireland or Jamaica. On the contrary, in both countries violent crime, particularly murder, became much worse after the bans. These cases should give pause to anyone who imagines that efforts to impose international controls on firearms will be successful in reducing criminal or political violence. The tendency in the last decade or two has been for the international community to assume that expensive programs such as universal registration will contribute to reducing death rates. Unfortunately, this crucial assumption is seldom rigorously examined. In reality, these proposals are put forward by naïve activists whose claims are based on wishful thinking rather than on solid 
academic research ${ }^{191}$.

\section{Econometric Analyses of Canadian Gun Laws}

As was seen in the previous section of this paper, trend analysis is valuable for showing the overall direction of crime patterns. Unfortunately, this approach does not provide any way to evaluate which factors are driving the crime trend. When legislation is introduced many other events occur at the same time, and it is quite possible that these other factors are more important than the legislation in determining whether crime rates increase or decrease. Econometric models enable the analyst to evaluate the unique contribution of each hypothesized causal factor by statistically controlling each one. In theory, this allows us to identify the importance of legislative changes in any drop (or rise) in the crime rate, amid the backdrop of other factors, such as demographic or economic variables, that are conceivably more powerful.

This section briefly summarizes three econometric studies of Canadian firearms laws. ${ }^{192}$ Each of these previously published studies uses a time-series model to estimate the effect the firearm legislation has on selected crime rates, after accounting for a large and varied selection of independent variables ${ }^{193}$. The first study (the 1992 study) evaluates the effect of the 1977 gun law

${ }^{190}$ Kopel, David B., op cit, 1992p 269.

${ }^{191}$ Despite dire predictions, neither the homicide nor the violent crime rates dramatically increased when New Zealand abandoned its efforts to register rifles and shotguns in 1983. See Thorpe, 1997, op cit.

${ }^{192}$ Gary Mauser and Richard Holmes, "An evaluation of the 1977 Canadian Firearms Legislation," EVALUATION REVIEW, December 1992, Vol. 16, No 6, pp 603-617; Gary Mauser and Dennis Maki, "Does Gun Control Reduce Criminal Violence? An Econometric Evaluation of Canadian Firearm Laws." Paper presented at American Society of Criminology, The Palmer House, November 12 - 16, 2002, Chicago, Illinois; Gary Mauser and Dennis Maki, "An Evaluation of the 1977 Canadian Firearms Legislation: Robbery Involving a Firearm," APPLIED ECONOMICS, Vol. 35, March 2003, pp. 423-436.

${ }^{193}$ Technically, it is a pooled cross-sectional, time-series model. See J. Kmenta, (1986). ELEMENTS OF ECONOMETRICS, SECOND EDITION, New York: Macmillan 
on the homicide rate, and the next two studies (the 2001 and 2002 studies) examine the impact of the 1977 and the 1991 firearm laws on robbery rates. In order to determine if firearm laws narrowly impact firearm crimes without reducing total robbery rates, three dependent variables were included, the total robbery rate as well as the rates of armed robbery and armed robbery involving a firearm. The data sets in each of these three models contain sociological, economic and police variables spanning 20 to 36 years for all ten Canadian provinces ${ }^{194}$. These models are based upon data sets that are among the largest ever assembled to evaluate Canadian legislation.

The success of any model to correctly estimate the causal strength of the firearm legislation depends upon the confidence one has that the model includes the most important social and economic forces. This is critical. One of the subtle but important differences between econometric models lies in which independent variables have been incorporated. The omission of important independent variables, called 'specification error,' may introduce a spurious correlation between the gun law and the crime rate being used as a dependent variable. Specification error is particularly important in criminology, where theory is too weak to completely identify which variables should be included or excluded from regression analyses.

To avoid specification error, two distinct strategies were employed. First, efforts were made to include as wide a set of relevant independent variables as possible in these time-series models. Second, a large number of alternative models were used to explore the sensitivity of the model on variations of critical decisions. The choice of independent variables was based upon those used by other researchers who had been identified after surveying a broad range of similar studies. Data availability was the most important limitation to the diversity of independent

\footnotetext{
194 These variables are discussed in greater detail in the following pages.
} 
variables that could be included. The breadth of our independent variables will increase the power of tests designed to isolate the effects of the firearm legislation while simultaneously reducing the probability of erroneously attributing to that legislation the effects of other variables.

In each model, four classes of independent variables are included: (a) variables pertaining to deterrence (e.g., clearance rates), (b) sociological variables (e.g., percentage male youth), (c) economic variables (e.g., unemployment rates), and (d) the effect of the firearm law under consideration. Previous studies have demonstrated the importance of variables pertaining to the likelihood of deterrence such as arrest and conviction rates ${ }^{195}$. The clearance rate is a useful index of the probability of a perpetrator being arrested and convicted ${ }^{196}$. Following Lott, the number of police effectives was included as a proxy for the probability of a perpetrator being caught, or for the differences in the proportion of crimes that are committed which are reported.

A number of researchers have argued that sociological variables, principally sex or ethnic differences, are important factors in crime rates ${ }^{197}$. These models included percentage of male youth in the population, various indices of immigration, as well as the aboriginal share of the

\footnotetext{
${ }^{195}$ See Erlich, I. (1975). The deterrent effect of capital punishment: a question of life and death. AMERICAN ECONOMIC REVIEW, 65: 397-417 and J. R. Lott, Jr. and D. Mustard. (1997). Crime, Deterrence, and Right -to-Carry Concealed Handguns, JOURNAL OF LEGAL STUDIES, Jan, 26(1):1-68

${ }^{196}$ Lott, J. R. Jr. (1998). MORE GUNS, LESS CRIME, UNDERSTANDING CRIME AND GUN CONTROL LAWS. University of Chicago Press, Chicago.

${ }^{197}$ See particularly, Lenton, Rhonda L. (1989). Homicide in Canada and the USA: A critique of the Hagan thesis. CANADIAN JOURNAL OF SOCIOLOGY 14(2): 163-178, Ouimet, Marc. (1999). Crime in Canada and in the United States: A Comparative Analysis. CANADIAN REVIEW OF SOCIOLOGY AND ANTHROPOLOGY, 36(3): 389-408, and Williams, Kirk. R. (1984). Economic sources of homicide: re-estimating the effects of poverty and inequality. AMERICAN SOCIOLOGICAL REVIEW. 49: 283-289.
} 
population. Immigration, both internal and international, has been linked with violent crime ${ }^{198}$. So in each of our studies we also took note of unpublished Canadian studies that have looked at immigration and crime rates ${ }^{199}$.

In these analyses, inter-provincial migration is distinguished from international migration in order to determine if their effects differ ${ }^{200}$. Immigrants may be involved in crime rates both as perpetrators and as victims. Immigration and ethnicity were both found in one study to be important factors in the Canadian homicide rate ${ }^{201}$. Ethnicity is an important factor in identifying who commits robbery in both Canada and the United States ${ }^{202}$. In Canada, aboriginal status has been found to be strongly linked with criminal violence and specifically homicide ${ }^{203}$. All independent variables are measured at the provincial level for all ten Canadian provinces.

\section{Study 1 - the 1992 Study.}

The 1992 study undercuts the claim that firearm legislation has caused the Canadian

${ }^{198}$ T.R. Gurr, (1989). Historical Trends in Violent Crime: Europe and the United States, in VIOLENCE IN AMERICA, THE HISTORY OF CRIME. Sage, New York, Lane, R. (1989). On the Social Meaning of Homicide Trends in America, in VIOLENCE IN AMERICA, THE HISTORY OF CRIME. Sage, New York, and Wilson, J. Q. and R. J. Herrnstein. (1985). CRIME AND HUMAN NATURE, Simon and Schuster, New York.

${ }^{199}$ Department of Justice. (1996). A STATISTICAL ANALYSIS OF THE IMPACTS OF THE 1977 FIREARMS CONTROL LEGISLATION, ED1996-1e, Queens Printer, Ottawa, Ontario, July, Samuel, T. J, and R. F. Santos. (1990). CANADIAN IMMIGRANTS AND CRIMINALITY. Unpublished report. Employment and Immigration, Canada and Thomas, D. (1990). CRIMINALITY AMONG THE FOREIGN BORN: PRELIMINARY ANALYSIS OF FEDERAL PRISON POPULATION. Rough draft. Ottawa: Strategic Planning, Immigration Policy Branch, Employment and Immigration Canada

${ }^{200}$ Previous research has found that international immigration is significantly correlated with violent crime rates. See Gary Mauser and Richard Holmes, 1992, op cit., and Department of Justice, 1996, op cit.

${ }^{201}$ Mauser and Holmes, 1992, op cit.

${ }^{202}$ Desroches, F. J. (1995). FORCE AND FEAR: ROBBERY IN CANADA. Nelson Canada, Scarborough, Canada.

${ }^{203}$ Silverman, R. A. and L. Kennedy. (1993). DEADLY DEEDS: MURDER IN CANADA. Nelson Canada, Scarborough, Canada. 
homicide rate to decline. In this study, firearm legislation was found to have no significant impact on the homicide rate ${ }^{204}$. See Figure 15.

This study analyzed the effect of six independent variables on the homicide rate for each province from 1968 through 1988. If the 1977 Firearm Law were to be effective in bringing down the homicide rate, as the government expected, it would be negatively associated with the Canadian homicide rate in this model. As can be seen in Figure 15, the gun law was indeed found to be negatively associated with the homicide rate, although not significantly. The other independent variables are all in the expected direction and statistically significant. The three most powerful independent variables were the percentage of Native Indians ${ }^{205}$, the percentage of international immigrants in a province, and the clearance rate.

Since all the independent variables are statistically significant, there cannot logically be any spurious correlations in this model. Thus, it was concluded that the 1977 firearm law did not have a significant impact on the Canadian homicide rate.

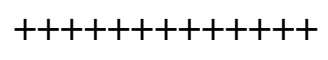

Figure 15. Evaluating the 1977 Gun Law on Homicide Rate

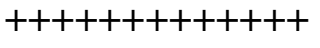

The next two studies examine the question of whether firearm legislation can reduce important types of violent crimes other than homicide, such as robbery and armed robbery.

\footnotetext{
${ }^{204}$ Mauser and Holmes, 1992, op cit.
} 


\section{Study 2 - the 2001 Study.}

The 2001 study found that the 1977 Canadian gun law was positively correlated with total robbery rates ${ }^{206}$. This study examined the impact of the gun law upon three related dependent variables: (a) armed robbery, (b) armed robberies involving firearms, and (c) total robberies for each province from 1974 through 1992.

Nine independent variables were included in the study in order to ensure that all of the important socioeconomic factors had been considered. The power of econometric analysis is that the model can statistically account for the most important other factors as co-variates. The most powerful independent variables were found to be the percentage of international immigrants in a province, the percentage of native Indians, the number of serving police officers per capita, and the clearance rate ${ }^{207}$.

$++++++++++++$

Figure 16. Evaluating the 1977 Gun Law on Robbery Rates

$+++++++++++++$

${ }^{205}$ In Canada, the amount of federal funding provided to native Indian reserves depends upon their population. In order to determine their population, the federal government requires that native Indians be registered.

${ }^{206}$ Gary Mauser and Dennis Maki, 2003, op cit. This study was conducted in 2001and submitted to the journal APPLIED ECONOMICS that same year. Unfortunately, publication was delayed until 2003.

${ }^{207}$ Multicollinearity is always a problem in econometric models. Multicollinearity is the distortion of the results by unknown patterns of correlations among the variables in the model. In order to examine the seriousness of this problem, the next two models calculated the results for regression models for all possible combinations of the independent variables, i.e., all 512 subsets of the 9 variables. This is a powerful way to evaluate the possibility of specification error as well. The analysis of the results of these equations strengthened the conclusions. The results are not a product of any particular combination of IV's. For further details, refer to Gary Mauser and Dennis Maki, 2003, op cit. 
The three dependent variables were analyzed separately, but the results were quite similar. Once the effects of the other variables were factored out, the Canadian gun law was found to have a significant effect. The original hypothesis was that the gun law would have a negative effect, that is, that restricting access to firearms would tend to reduce robbery and armed robbery rates. Unexpectedly, the effect of the gun was found to be positive; just the opposite of that hypothesized. In other words, the gun law acted as if it increased criminal violence. The effect was marginal, but significant. It was tentatively concluded that the 1977 firearm law significantly increased robbery and more specifically armed robbery with a firearm.

Some researchers have argued that restrictive firearms laws generally cause crime rates to increase $^{208}$, while this may well be true, because of the marginality of the result, professors Maki and Mauser were reluctant to accept this conclusion without further research. It is always possible that an anomalous result may be due to an accidental misspecification of the model. Therefore it was decided to conduct a third study.

\section{Study 3 - the 2002 Study.}

The failure of Canadian firearms laws was confirmed in a 2002 study that investigated the effects of both the 1977 and the 1991 firearms legislation in the same model ${ }^{209}$. This involved comparing changes over the following time periods: The 1997 law: 17 years before the 1977 law,

\footnotetext{
${ }^{208}$ John R. Lott, Jr, 1998, op cit.

${ }^{209}$ Gary Mauser and Dennis Maki, op cit, 2002.
} 
[62 - 78] and 19 years afterwards [79 through 97], and the 1991 law: 30 years before the 1991 law, [62 - 92] and 5 years afterwards [93 through 97].

The database in this study differs from those used in earlier papers primarily in its length. It is the longest data series ever collected in Canada to evaluate legislation. The data set extends from 1962 through 1997, while the database used in the 2003 paper $^{210}$, only runs from 1974 through 1992.

The primary goal of this study was to confirm the finding of our previous study that the 1977 Canadian gun law actually caused robbery rates to increase. After gradually increasing throughout the 1970s and 1980s, robbery rates started declining in the 1990s. What could explain this pattern? The decline is consistent with the hypothesis that it is due to the firearm legislation. However, there were several other factors occurring at the same time that have been hypothesized to be the primary driving forces behind robbery rates, e.g., aging population, immigration rates or patterns, economic conditions, social conditions, and finally police numbers or activity. If the most important factor is the firearm legislation, then statistically controlling the other factors that occurred at the same time will allow the effect of the legislation to be revealed more clearly. Alternatively, the legislation may not be as powerful as hypothesized. It is logically possible that these other factors are more important in causing the observed change. If so, statistical control will demonstrate this as well as uncovering the factors that are more important.

As had been done in the two previous models, in order to avoid specification error, the widest possible set of relevant variables were included in these time-series models. In this model, nine other independent variables were included in order to investigate as possible confounding 
factors. As before, the basic question is to discover whether other factors could account for the changes in the dependent variable, the robbery rate, rather than the firearm legislation.

The results from the 2002 study were clear: the model could not find a significant effect from either the 1977 gun law or the 1991 gun law. The results showed that the two most important variables were the percentage of registered native Indians and the percentage of young males in a province. The foreign immigration rate and the police clearance rate were also statistically significant, but were of lesser importance. Almost all of the statistically significant relationships were found to be in the expected direction.

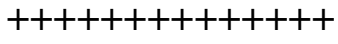

Figure 17. Evaluating the 1977 and 1991 Gun Laws on Robbery Rate

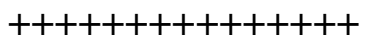

In summary, there was no persuasive support for the hypothesis that Canadian firearms laws (either the 1977 or 1991 laws) had a significant effect on robbery or homicide rates - either positively or negatively. One study, the 2001 study, found that the 1977 law significantly increased robbery rates. However, the significance disappeared in a subsequent study, which had a larger and more complete database. The failure of the significance of this relationship to survive replication suggests that it was an aberrant result.

The independent variables that were found to have the largest effect in the three studies were the provincial percentage of young males and percentage Native Indian. Two other

\footnotetext{
${ }^{210}$ Gary Mauser and Dennis Maki, 2003, op cit.
} 
independent variables, the percentage of foreign immigrants and the clearance rate, were also found to be significantly related to violent crime rates, but the strength of these relationships were not as powerful as the first two independent variables. The remaining independent variables were not found consistently to have significant effects.

\section{CONCLUSION}

This article has reviewed a goodly amount of evidence from a wide variety of international sources. Each individual portion of evidence is subject to cavil, at the very least the general objection that the persuasiveness of social scientific evidence cannot remotely approach the persuasiveness of conclusions in the physical sciences. Nevertheless the burden of proof rests on the proponents of the "more guns = more death/fewer guns = less death mantra, especially since they propose public policy ought to be based on that mantra To bear that burden would at the very least require showing that a large number of nations with more guns have more death and that nations which imposed stringent gun controls achieved substantial reductions in criminal violence (or suicide). But those things are precisely what is not demonstrated when a large number of nations are compared across the world.

Over a decade ago University of Washington public health professor Brandon Centerwall undertook an extensive, statistically sophisticated study comparing areas in the U.S. and Canada to determine whether Canada's much more restrictive policies had better contained criminal violence. When he published his results it was with the admonition:

If you are surprised by my findings, so are we. We did not begin this research with any 
intent to "exonerate" handguns, but there it is -- a negative finding, to be sure, but a negative finding is nevertheless a positive contribution. It directs us where NOT to aim public health resources. $^{211}$

${ }^{211}$ Brandon Centerwall, "Homicide and the Prevalence of Handguns: Canada and the United States, 1976 to 1980", AMERICAN JOURNAL of EPIDEMIOLOGY v. 134 pp. 1245-65 (1991.). Papers reaching similar conclusions about Canadian gun control, or aspects thereof, include: Robert Mundt, "Gun Control and Rates of Firearms Violence in Canada and the United States" 32 CANADIAN J. OF CRIMINOLOGY 137-153 (1990); David B. Kopel, "Canadian Gun Control: Should the United States Look North for a Solution to its Firearms Problem", 5 TEMPLE INT'L \& COMP. L. J. 1 (1991), Rich, et al. "Guns and Suicide: Possible Effects of Some Specific Legislation" 147 AM. J. PSYCHI. 342 (1990). 
TABLE 1: Europe \& Scandinavia - Gun Ownership \& Murder Rates

[rates given are per 100,000 people and in descending order]

$\underline{\text { NATION }}$

Russia

Luxembourg

Hungary

Finland

Sweden

Poland

France

Denmark

Greece

Switzerland

Germany

Norway

Austria

Notes for Table:
MURDER RATE

$20.54 \quad[2002]$

$9.01 \quad$ [2002]

$2.22 \quad[2003]$

1.98 [2004]

1.87 [2001]

$1.79 \quad[2003]$

1.65 [2003]

$1.21 \quad$ [2003]

$1.12 \quad$ [2003]

$0.99 \quad$ [2003]

$0.93 \quad$ [2003]

$0.81 \quad$ [2001]

$0.80 \quad$ [2002]

\section{RATE OF GUN OWNERSHIP}


This table covers all the Continental European nations for which the two data sets given are both available. In every case we have given the homicide data for 2003 or the closest year thereto because that is the year of the publication from which the gun ownership data are taken. That publication is the Graduate Institute of International Studies', SMALL ARMS SURVEY 2003 (Oxford U. Press 2003) at pp. 64 and 65, tables 2.2 ("Known Civilian Firearms in the European Union" and 2.3 ("Known Civilian Firearms in Other European Countries"), The homicide rate data come from the pamphlets JURISTAT: Homicide in Canada (Canadian Centre for Justice Statistics) for the years 2001-04. Each year's pamphlet gives homicide statistics for a dozen or so foreign nations in a section labeled "Homicide Rates for Selected Countries." This section of the pamphlets gives no explanation of why it selects the various nations whose homicide statistics it covers. Moreover, also without explanation, the nations covered differ from year to year. Thus, for instance: murder statistics for Germany and Hungary are given in all four of the pamphlets (2001, 2002, 2003, 2004); for Russia are given in three years (2001, 2002, and 2004), for France in two years (2001 and 2003), and for Norway and Sweden in only one year (2001). 
TABLE 2: Murder Rates of European Nations Which Ban Handguns As Compared to Their Neighbors Which Allow Handguns (rates are per 100,000 persons)

$\underline{\text { Nation }} \quad \underline{\text { Handgun Policy }} \quad \underline{\text { Murder Rate }} \quad \underline{\text { Year }}$
A. Belarus
banned
10.40
late $1990 \mathrm{~s}$

[Neighbors for which I have gun law and murder rate data]

$\begin{array}{llll}\text { Poland } & \text { allowed } & 01.98 & 2003\end{array}$

$\begin{array}{llll}\text { Russia } & \text { banned } & 20.54 & 2002\end{array}$

B. Luxembourg banned $\quad 09.01 \quad 2002$

[Neighbors for which I have gun law and murder rate data]

$\begin{array}{llll}\text { Belgium } & \text { allowed } & 01.70 & \text { late 1990s }\end{array}$

$\begin{array}{llll}\text { France } & \text { allowed } & 01.65 & 2003\end{array}$

$\begin{array}{llll}\text { Germany } & \text { allowed } & 00.93 & 2003\end{array}$ 


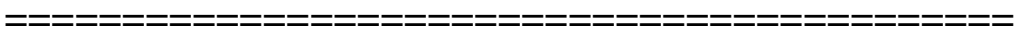

$\begin{array}{llll}\text { C. Russia } & \text { banned } & 20.54 & 2002\end{array}$

[Neighbors for which I have gun law and murder rate data]

$\begin{array}{llll}\text { Belarus } & \text { allowed } & 10.40 \quad \text { late 1990s }\end{array}$

$\begin{array}{llll}\text { Finland } & \text { allowed } & 01.98 & 2004\end{array}$

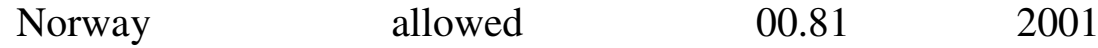

++++++++++++++++++++++++++++++++++++++++++ 


\section{TABLE 3: Eastern Europe -Gun Ownership \& Murder Rates}

[rates given are per 100,000 people and in descending order]]

NATION $\underline{\text { MURDER RATE }}$ RATE OF GUN OWNERSHIP

$\begin{array}{llll}\text { Russia } & 20.54 & {[2002]} & 4,000\end{array}$

$\begin{array}{lll}\text { Moldova } & 07.81 & 1,000\end{array}$

$\begin{array}{lll}\text { Slovakia } & 02.63 & 3,000\end{array}$

$\begin{array}{lll}\text { Romania } & 02.50 & 300\end{array}$

$\begin{array}{lll}\text { Macedonia } & 02.29 & 16,000\end{array}$

$\begin{array}{lll}\text { Hungary } & 02.22 & {[2003]}\end{array}$

$\begin{array}{lll}\text { Finland } & 01.98 & {[2004]}\end{array}$

$\begin{array}{lll}\text { Poland } & 01.79 & {[2003]}\end{array}$

$\begin{array}{lll}\text { Slovenia } & 01.79 & 5,000\end{array}$

$\begin{array}{lll}\text { Cz. Republic } & 01.69 & 5,000\end{array}$

$\begin{array}{lll}\text { Greece } & 01.12 & {[2003]}\end{array}$

Notes for Table:

This table covers all the Eastern European nations for which we have data as to both gun 
ownership and murder rates. The gun ownership rate data come from the Graduate Institute of International Studies' SMALL ARMS SURVEY 2003 (Oxford U. Press 2003) at p.65, table Known Civilian Firearms in Other European Countries" ["other" than those nations which are in the European Union]. For about half the nations in this Table the murder rate data come from the pamphlets JURISTAT: Homicide in Canada (Canadian Centre for Justice Statistics) for the years 2001-04., In each case the date of the pamphlet is specified after the murder rate in the Table.. As to the other nations listed in the Table, the murder rate data are from the Seventh United Nations Survey of Crime Trends and Operations of Criminal Justice Systems, covering the period 1998 2000 (United Nations Office on Drugs and Crime, Centre for International Crime Prevention.).

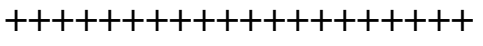




\section{Table 4 [1]: Intentional Deaths: U.S. vs. Continental Europe Rates}

In order of highest combined rate; nations having rates higher than the U.S are indicated by asterisk (suicide rate) or + sign (murder rate).

[N.B. These data should be considered in light of Tables 2 and 3 and the Explanatory Note which precedes Table 3.]

Suicide

Murder

RUSSIA

ESTONIA

LATVIA

LITHUANIA

$45.6^{*}$

$11.7+$

57.3

BELARUS

HUNGARY

$32.9 *$

03.5

$27.9 * \quad 10.4+$

38.3

UKRAINE

Combined rates

71.8

62.3

58.9

36.4 
SLOVENIA

FINLAND

DENMARK

CROATIA

AUSTRIA

BULGARIA

FRANCE

SWITZ.

BELGIUM

U.S.

POLAND
28.4*

2.4

30.4

$27.2 *$

2.9

30.1

$22.3 *$

4.9

27.2

$22.8^{*}$

3.3

26.1

$22.2^{*}$

1.0

23.2

$17.3 *$

5.1

22.4

$20.8^{*}$

1.1

21.9

21.4*

1.1 [2]

24.1

$18.7^{*}$

1.7

20.4

11.6

7.8

19.4

$14.2 *$

2.8

17.0 


\begin{tabular}{|c|c|c|c|}
\hline GERMANY & $15.8^{*}$ & 1.1 & 16.9 \\
\hline ROMANIA & $12.3 *$ & 4.1 & 16.4 \\
\hline SWEDEN & $15.3^{*}$ & 1.0 & 16.3 \\
\hline NORWAY & $12.3^{*}$ & 0.8 & 13.1 \\
\hline HOLLAND & 9.8 & 1.2 & 11.0 \\
\hline ITALY & 8.2 & 1.7 & 09.9 \\
\hline PORTUGAL & 8.2 & 1.7 & 09.9 \\
\hline SPAIN & 08.1 & 0.9 & 09.0 \\
\hline GREECE & 03.3 & 1.3 & 04.6 \\
\hline
\end{tabular}

\section{NOTES}

1. Based in general on U.N. Demographic Yearbook (1998) as reported in David C. Stolinsky, 
"America: The Most Violent Nation?" Medical Sentinel v. 5 (\# 6 2000) 199-201. It should be understood that, though the 1998 YEARBOOK gives figures for as late as 1996, the figures are not necessarily for that year. The YEARBOOK contains the latest figure each nation has provided the U.N. which may be 1996, 1995, or 1994.

2. The Swiss homicide figure Stolinsky, supra, reports is an error because it combines attempts wth actual murders. We have computed the Swiss murder rate by averaging the 1994 and 1995 Swiss National Police figures for actual murders in those years given in R.A.I. Munday \& J.A. Stevenson, GUNS AND VIOLENCE: THE DEBATE BEFORE LORD CULLEN (Essex, Eng., Piedmont: 1996) at p. 268.

[N.B. The following data should be considered in light of Tables 1 and 3 and the Explanatory Note which precedes Table 3.] 
Table 5 [1]: European Gun/Handgun Violent Death

\begin{tabular}{|c|c|c|c|}
\hline Suicide & Murder & $\%$ households & $\%$ households \\
\hline & & with guns & with handgun \\
\hline
\end{tabular}

$\begin{array}{lcccc}\text { BELGIUM } & 18.7 & 01.7 & 16.6 \% & 06.8 \\ \text { FRANCE } & 20.8 & 01.1 & 22.6 \% & 05.5 \\ \text { W.GERMANY } & 15.8 & 01.1 & 08.9 \% & 06.7[2] \\ \text { HOLLAND } & 09.8 & 01.2 & 01.9 \% & 01.2 \\ \text { ITALY } & 08.2 & 01.7 & 16.0 & 05.5 \\ \text { NORWAY } & 12.3 & 00.8 & 32 \% & 03.8 \\ \text { SWEDEN } & 15.3 & 01.3 & 15.1 & 01.5 \\ \text { SWISS } & 20.8 & 01.1[3] & 27.2 & 12.2 \\ \text { +++++++++++++++++++++++++++++++++++++++++++++++++++++++ }\end{array}$

\section{NOTES}

1. As to derivation of the homicide rates see Table 1 , note 1 . The data on household firearms ownership come from British Home Office figures printed in R.A.I. Munday \& J.A. Stevenson, GUNS AND VIOLENCE: THE DEBATE BEFORE LORD CULLEN (Essex, Eng., Piedmont: 1996) pp. 30 and 275.

2. Note that the data here are for West Germany and were obtained when that nation still existed as an independent entity. See Table 3 infra for later (but differently derived) data for the current 
nation of Germany.

3. Again, the Swiss homicide figure Stolinsky, supra, reports is an error because it combines attempts with actual murders. See Note 2 for Table 1.

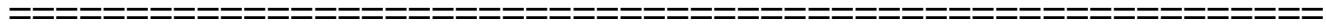


Explanatory Note to Table 3: It bears emphasis that the following data come from a

special U.N. report whose data are not fully comparable to those in Tables 1 and 2

because they cover different years and derive from substantially differing sources. ${ }^{212}$ This

special report is based on data obtained from the governments of the nations set out

below, especially data on gun permits or other official indicia of gun ownership in those

nations. ${ }^{213}$ The data on suicide and murder in those nations also come from their

governments as do the similar data in Tables 1 and 2, but for later years, and also include

data on the number of firearm homicides and firearm suicides which are not available

from the U.N. source used in Tables 1 and 2.

\footnotetext{
1. The data derive from a much more extensive survey of legal firearms ownership in numerous nations which was carried out by researchers provided by the Government of Canada under the auspices of the United Nations Economic and Social Council, Commission on Crime Prevention and Criminal Justice in 1997. The entire survey is published as a report to the Secretary General on April 25, 1997 as E/CN.15/1997/4. That report is analysed in some detail in an unpublished paper ("A Cross Sectional Study of the Relationship Between Levels of Gun Ownership and Violent Deaths") written by the leading English student of firearms regulation, retired Chief Superintendent of English police Colin Greenwood of the Firearms Research and Advisory Service. I am indebted to Chief Superintendent Greenwood for the opportunity to review his paper. Note that in the table which followsI have focused only on European nations.

${ }^{2}$. The gun ownership data in Table 2 derive from a random telephone survey on gun ownership in various nations. Chief Superintendent Greenwood's paper is contemptuous of such data, inter alia because people may be unwilling to acknowledge owning guns to telephoning pollsters. For similar doubts see Don B. Kates \& Daniel D. Polsby, "Long Term Non-Relationship of Firearm Availability to Homicide," 4 HOMICIDE STUDIES 185-201 (2000). But that was in the context of comparing survey data on the number of guns owned to production and important data that are unquestionably more comprehensive and superior in every way. Chief Superintendent Greenwood himself admits that the special U.N. report data are not necessarily comprehensive and are problematic in various other respects. Even assuming they are clearly superior to the survey data, the latter cover multiple nations that the special U.N. report does not. Given that neither source is indubitable, it seems preferable to have such information on those nations as the survey data reveal, rather than no data at all.
} 
Table 6: European Firearms-Violent Deaths

\begin{tabular}{|c|c|c|c|c|}
\hline Suicide & Suicide & Murder & Murder & \# of guns \\
\hline & W/ gun & & W/ gun & Per 100,000 \\
\hline
\end{tabular}

\begin{tabular}{|c|c|c|c|c|c|}
\hline AUSTRIA & n.a. & n.a. & 2.14 & 0.53 & $41.02[1]$ \\
\hline BELARUS & 27.26 & n.a & 9.86 & n.a & 16.5 \\
\hline CZECH R. & 9.88 & 1.01 & 2.80 & 0.92 & 27.58 \\
\hline ESTONIA & 39.99 & 3.63 & 22.11 & 06.2 & 28.56 \\
\hline FINLAND & 27.28 & 5.78 & 3.25 & 0.87 & 411.20 [2] \\
\hline GERMANY & 15.80 & 1.23 & 1.81 & 0.21 & 122.56 \\
\hline GREECE & 3.54 & 1.30 & 1.33 & 0.55 & 77.00 \\
\hline HUNGARY & 33.34 & 0.88 & 4.07 & 0.47 & 15.54 \\
\hline MOLDOVA & n.a & n.a & 17.06 & 0.63 & 6.61 \\
\hline POLAND & 14.23 & 0.16 & 2.61 & 0.27 & 5.30 \\
\hline ROMANIA & n.a & n.a & 4.32 & 0.12 & 2.97 \\
\hline SLOVAKIA & 13.24 & 0.58 & 2.38 & 0.36 & 31.91 \\
\hline SPAIN & 5.92 & n.a & 1.58 & 0.19 & 64.69 \\
\hline SWEDEN & 15.65 & 1.95 & 1.35 & 0.31 & 246.65 \\
\hline
\end{tabular}




\section{NOTES}

${ }^{[1]}$. This may well be an undercount because an Austrian licence is not limited to a single firearm but rather allows the licensee to possess multiple guns.

${ }^{[2]}$. The source from which Table 2 derives also gives figures for Finland which we have omitted there because they are earlier and closely similar except in one respect: instead of official ownership figures for guns they give a survey-based figure for households having a gun: $23.2 \%$ 